\title{
The Future of Content Regulation in Broadcasting
}

In the years since Congress enacted the Communications Act of $1934,{ }^{1}$ technological, structural, and professional developments in the communications industry have, to a significant extent, made that legislation obsolete. The Act has been amended from time to time, ${ }^{2}$ but many of its provisions are still in need of major reform. Among these are many of the rules governing radio and television broadcasting. ${ }^{3}$ Developments in the broadcast industry, such as the rise of national networks ${ }^{4}$ and the mcreased professionalism of broadcast journalists, ${ }^{5}$ have been largely unaddressed by the statutory language. The Federal Communications Commission (FCC), with its broad regulatory authority, ${ }^{6}$ has been able to ameliorate some of the problenis created by this legislative obsolescence, ${ }^{7}$ but the Commission is constrained by congressional directives and, some contend, by its own biases. ${ }^{8}$

Recently, several bills have been imtroduced in Congress that would attempt to bring broadcast regulation up to date. Some would achieve this goal by comprehensively amending the 1934 Act, ${ }^{9}$ others by conpletely rewriting the Act. ${ }^{10}$ A coinmon feature of these bills is

1. Ch. 652,48 Stat. 1064 (1934) (current version at 47 U.S.C. $\S \S 151-609$ (1976 \& Supp. II 1978)).

2. E.g., Pub. L. No. 86-274, 73 Stat. 557 (1959), amending 47 U.S.C. $\$ 315$.

3. 47 U.S.C. $\$ \S 301-399$ (1976 \& Supp. II 1978).

4. Over eighty percent of commercial television programming is now derived from the three major networks and national syndication companies. House SUBCOMM. ON COMMUNICAtions of the Comm. on Interstate and Foreign Commerce, 95th Cong., Ist Sess., OpTIONS PAPERS 54 (Subcomm. Print 1977) [hercinafter cited as OptIons PAPERS].

5. This has been noted, for example, by Senator Proxmire in his testimony before the Senate Commerce Cominittee. First Amendment Clarification Act of 1977: Hearings on S. 22 Before the Subcomm. on Communications of the Senate Comm. on Commerce, Science, and Transportation, 95th Cong., 2d Sess. 7 (1977-1978) (statement of Sen. Proxmire) [hereinafter cited as 1977 Hearings].

6. This authority is granted under 47 U.S.C. $§ 151$ (1976).

7. For example, the FCC has increased local programming not doininated by the inajor networks by mandating that some prine time be reserved for such programming. 47 C.F.R. $\S 73.658$ (1979).

8. Several commentators have alleged that the FCC has been "captured" by those it was intended to regulate and is therefore too deferential to established broadcasters, particularly the VHF television stations. See, e.g., Robinson, The Federal Communications Commission: An Essay on Regulatory Watchdogs, 64 VA. L. REv. 169, 189 (1978).

9. E.g., S. 622, 96th Cong., 1st Sess., 125 Cong. Rec. S2525 (daily ed. Mar. 2, 1979).

10. E.g., H.R. 3333, 96th Cong., 1st Sess., 125 CoNG. REC. H1 860 (daily ed. Mar. 29, 1979). 
language that would eliminate the fairness doctrine, ${ }^{11}$ a set of rules regulating the content of broadcast expression.

Presently embodied in section 315 of the Communications Act, ${ }^{12}$ the fairness doctrine represents an interesting confiuence of technological regulation and first amendment theory that has spawned a considerable amount of litigation and scholarly debate. ${ }^{13}$ On the one hand, the doctrine permits a level of government intrusion into the editorial processes of broadcast journalists that would be constitutionally impermissible with the print medium. ${ }^{14}$ On the other liand, the scarcity inherent in the broadcast spectrum limits the number of speakers who can exercise their right of free speech over the airwaves. This conflict is the major focus of this Comment.

If Congress does abolish the fairness doctrine, an individual or group that favors government regulation of broadcast content would be likely to bring an action requesting judicial reimposition of such regulation. ${ }^{15}$ This lawsuit would be predicated on an asserted right of the

11. For a brief description of the fairness doctrine, see notes 52-70 and accompanying text infra.

12. 47 U.S.C. § 315(a) (1976) (emphasis added):

If any licensee shall permit any person who is a legally qualified candidate for any public office to use a broadcasting station, he shall afford equal opportunities to all other such candidates for that office in the use of such broadcasting station: Provided, That such licensee shall have no power of censorship over the material broadcast under the provisions of this section. No obligation is imposed under this subsection upon any licensee to allow the use of its station by any such candidate. Appearance by a legally qualified candidate on any-

(1) bona fide newscast,

(2) bona fide news interview,

(3) bona fide news documentary (if the appearance of the candidate is incidental to the presentation of the subject or subjects covered by the news documentary), or

(4) on-the-spot coverage of bona fide news events (includimg but not limited to political conventions and activities incidental thereto),

shall not be deemed to be use of a broadcasting station within the meaning of this subsection. Nothing in the foregoing sentence shall be construed as relieving broadcasters, in connection with the presentation of newscasts, news interviews, news documentaries, and onthe-spot coverage of news events, from the obligation imposed upon them under this chapter to operate in the public interest and to afford reasonable opportunity for the discussion of conflicting views on issues of public importance.

13. For an exhaustive compilation of commentary on the fairness doctrine, see Lange, The Role of the Access Doctrine in the Regulation of the Mass Media: A Critical Review and Assessmcnt, S2 N.C. L. Rev. 1, 2 n.5 (1973).

14. Compare Red Lion Broadcasting Co. v. FCC, 395 U.S. 367 (1969) with Miami Herald Publishing Co. v. Tornillo, 418 U.S. 241 (1974).

15. Content regulation, the subject of this Comment, is not the same as access to the media. Where content regulation envisions the presentation of opposing viewpoints on a variety of public issues, access would grant to all persons the opportunity to have their viewpoints heard, but would rely on the "multiplicity of voices," see United States v. Associated Press, 52 F. Supp. 362, 372 (S.D.N.Y. 1943) (three-judge court) (per Hand, J.), aff'd, 326 U.S. 1 (1945), to provide the diversity desired. Thus, the constitutionality of a government-enforced right of access to broadcasting will not be considered here. For a discussion of access, see Lange, supra note 13. A "right" of access probably would not be constitutionally compelled, see notes 234-51 and accoinpanying text 
public to obtain diverse viewpoints over the airwaves on controversial issues of public importance, a right asserted to prevail over the general constitutional mandate against content-based regulation of speech. ${ }^{16}$ The plaintiffs would argue that this interest in diverse viewpoints requires government regulation even where such regulation interferes with the individual broadcaster's right to free speech and a free press. ${ }^{17}$

Such a lawsuit could arise under two sets of circuinstances. In the first, an individual or group might deinand that a station present programming on a particular issue that liad been either ignored or inadequately covered by the broadcaster. ${ }^{18}$ In the second, after a broadcaster has presented one side of an issue, the individual or group could demand that the other side be presented as well. If the broadcaster refuses the demand in eitlier instance, the individual or group could then sue the broadcaster to compel it to ineet the demand, alleging that access over the airwaves to information and viewpoints on important public issues is mandated by the first anendment. ${ }^{19}$

This Comment argues that the plaintiff has standing to bring his claim before the court, and that the court slould find state action in the broadcaster's refusal to provide the desired balance, but concludes that an analysis of both the first ainendinent rights involved and the remedy requested should compel a demal of the rehef sought. The "right to

infra, but it probably would be constitutional if mandated by legislative action. Since the federal government retains ultimate control over use of the electromagnetic spectrum, see, e.g., WNCN Listeners Guild v. FCC, 610 F.2d 838, 857 (D.C. Cir. 1979), cert. granted, 445 U.S. 914 (1980), it can determine its allocation among those who wish to use it. One such allocation would be to permit broadcast hicensees the privilege of exclusive use of a particular wavelength for only part of the broadcast day, opening it to public use for the remaining time.

16. "[A]bove all else, the First Amendment means that government has no power to restrict expression because of its message, its ideas, its subject matter, or its content." Police Dept. v. Mosley, 408 U.S. 92, 95 (1972). Exceptions to this rule - such as the clear and present danger doctrime, see Dennis v. United States, 341 U.S. 494 (1951), and time, place, and manner restrictions, see Cox v. Louisiana, 379 U.S. 559 (1965)-are rare.

17. While only the print medium is universally considered a part of the press, it is the position of this Comment that the broadcast medium is equally a component of the press for first amendmeut purposes. See, e.g., Rosenbloom v. Metromedia, Inc., 415 F.2d 892, 895 (3d Cir. 1969), aff'd, 403 U.S. 29 (1971) (in a defamation context, the court stated that "[r]adio and television were, of course, unknown media when freedom of the press was written into the Bill of Rights, but no rational distinction can be made between radio and television on the one hand and [the print medium] on the other in affording the constitutional protection contemplated by the First Amendment."). See also notes 157-223 and accompanying text infra. Both perform, to a large extent, the same function: presenting news and commentary on important public issues. Both have achieved high levels of journalistic professionalism. And both are looked to by the public for information. See note 165 infra. Thus, for first amendment purposes, the print and broadcast media are both components of the press.

18. For such an occurrence under the fairness doctrine, see Representative Patsy Mink (WHAR), 59 F.C.C.2d 987 (1976).

19. For a discussion in support of this hypothesis, see, e.g., Barron, Access to the Press $-A$ New First Amendment Right, 80 HARv. L. Rev. 1641 (1967). 
hear" embodied in the first amendment is mapplicable in this situation for two reasons. First, its application in the manner requested would entail a substitution by government of one speaker for another rather than a prohibition of government interference with communication. Such a substitution, because it would deny the origmal speaker his right to free speech, cannot be permitted. Second, applying the "right to hear" doctrine to broadcast content regulation would weaken the essential role of a free press in the mamtenance of a democratic society, a role that the first amendment was intended to strengthen. It would invite government abuse by giving the state the authority to determine what is "fair" and to mandate what must be presented by the press. Content regulation would tend to promote homogeneity within the mass media and weaken the advocacy role of the press.

Even if the court finds such a right to exist, it should deny the remedy requested. The right of the public to receive information and opinions on inportant issues is adequately served through the marketplace, which includes not only the broadcast medium, but other means of communication as well. Moreover, a remedy requiring broadcasters to present a balanced coverage of public issues would be likely to mhibit broadcasters, causing them to reduce coverage of important public issues due to the costs associated with a fairness requirenient and the possibility of government sanctions for a failure to meet that requirement. This effect would not be justified by a compelling state imterest in providing adequate access to information and opinions in order to foster democratic decisionmaking. That interest would be better served through the marketplace or through alternative, less inhibiting government actions.

Part I of this Comment traces the evolution of government regulation of the broadcast industry and the advent of content regulation, describes the fairness doctrine, and exammes the recent attempts to repeal it. Part II discusses standing and state action, threshold issues in any litigation challenging content selection. Part III analyzes the possible legal distmctions between the primt and broadcast media, and sets forth the proper balance of the first amendment interests at stake.

Regulation and Deregulation of Broadcasting

\section{A. The Rise of Regulation}

The broadcast era formally began in 1921, when the Department of Commerce, acting pursuant to its authority under the Radio Act of 
1912 to regulate radio communication, ${ }^{20}$ adopted "broadcasting" as a separate class of radio station ${ }^{21}$ and started to issue broadcast licenses. ${ }^{22}$ At first, this development presented little difficulty to Secretary of Commerce Hoover: He set $833.3 \mathrm{Kc}$ as the wavelength for most broadcast purposes, with $618.6 \mathrm{Kc}$ reserved for weather and crop reports, and issued only five licenses in the first eleven months of the year. ${ }^{23}$ What started as a trickle, however, soon became a deluge, as stations rushed to get on the air. In Deceniber 1921, the Department of Commerce issued twenty-three hicenses; ${ }^{24}$ by the end of 1922 , the number had grown to more than $564 . .^{25}$

As the number of stations grew, so did the problem of interference, as several stations often attempted to use the same wavelength in the same city at the same time. ${ }^{26}$ Time-sharing arrangements enjoyed sonie early success in dealing with this problem, ${ }^{27}$ but before long such cooperation between broadcasters broke down, and the airwaves once agam becanie a virtual cacophony of voices. Unsure of his regulatory powers under the 1912 Act, Hoover nevertheless realized that some action had to be taken if bedlam was to be averted. He established a third broadcast wavelength at $750 \mathrm{Kc},{ }^{28}$ and attempted to relieve congestion by limitimg the number of licenses issued. ${ }^{29}$ This latter control was lost, however, in February 1923, when the Court of Appeals for the District of Columbia Circuit held that the Secretary's duty in issumg licenses was ministerial only. ${ }^{30}$ Thus, he was required to issue a license to any apphicant meetimg the statutory requirements, and a writ of mandamus would lie to compel its issuance. ${ }^{31}$ As a result, hundreds of new stations went on the air, started by colleges and universities, newspapers, and churches; a few were even operated by rich men as a hobby. ${ }^{32}$

Everyone agreed that government regulation of the radio imdustry

20. Ch. 287, 37 Stat. 302 (1912), repealed, Act of June 19, 1934, ch. 652, §602(a), 48 Stat. 1102.

21. Other uses of the electrounagnetic spectrum include "Inarine, aviation, amateur, military, and common carrier" uses. Red Lion Broadcasting Co. v. FCC, 395 U.S. 367, 397-98 (1969).

22. E. BARNOUW, A TOWER IN BABEL 94 (1966).

23. Id. at 92 .

24. Id.

25. Id. at 288; Options PAPERs, supra uote 4, at 99.

26. For example, there were 23 stations sharing the same wavelength $(833.3 \mathrm{Kc})$ in Los Angeles in 1923. Options PAPERS, supra note 4, at 99.

27. E. BARNOUw, supra note 22 , at $92-94$.

28. The use of this wavelength, however, was limited to those stations with 500-1000 watts of output. Very few stations could operate at this power. This action resulted in the creation of an elite group of stations that could operate relatively free of interference, but it did hittle to alleviate the chaos at $833.3 \mathrm{Kc}$. Id. at $100-01$.

29. Id. at 174 .

30. Hoover v. Intercity Radio Co., 286 F. 1003 (D.C. Cir. 1923).

31. Id. at 1007 .

32. E. BARNOUW, supra note 22 , at $97-99$. 
was necessary, ${ }^{33}$ but Congress failed to act. ${ }^{34}$ Buoyed only by industry support, ${ }^{35}$ Secretary Hoover, still unconvinced of his authority to regulate, acted once again to alleviate the confusion on the airwaves. $\mathrm{He}$ established a radio spectrum, within which all but the least powerful of stations could operate without interference, assigned wavelengths, and regulated the power and hours of operation of stations. ${ }^{36}$

By the end of 1925, the situation again liad become critical. Nearly every wavelength reserved for broadcasting was occupied by at least one station, and applications continued to mount. ${ }^{37}$ Then, in early 1926, federal regulation of radio broadcasting under the 1912 Act received its deatli blow. In United States $v$. Zenith Radio Corp.$^{38}$ the United States District Court for the Northern District of Illinois held that the Secretary of Commerce had no autliority to prescribe regulations beyond those contained in the 1912 Act itself. A vigorous appeal by the government, to the United States Supreme Court if necessary, was anticipated ${ }^{39}$ Less than three nionths later, lowever, the Attorney General issued a report that came to the same conclusion, stating that Hoover had no power to assign wavelengths, regulate hours of operation, or limit the power of stations. ${ }^{40}$ Stripped of his authority to act, Hoover abandoned all attempts at regulation, and urged industry selfcontrol. ${ }^{41}$

The result was chaos, as stations inoved to more desirable wavelengths at will, imcreased transmission power, and operated at whatever hours they wished. ${ }^{42}$

In February 1927, Congress finally responded to this crisis by enacting the Radio Act of $1927.0^{43}$ The Act created a new regulatory agency, the Federal Radio Commission, ${ }^{44}$ and gave it a broad range of powers, including the authority to assign wavelengths, to determine sta-

33. At the first Washington Radio Conference, held in February 1922, Hoover said that "this is one of the few instances where the country is unanimous in its desire for more regulation." $I d$. at 95 (quoting radio broadcast, May 1922).

34. Several bills had been imtroduced im Congress to provide the regulation needed. None passed. OPTIONS PAPERS, supra note 4, at 100.

35. The Second Washington Radio Conference, in response to Hoover's plea, went on record as expressimg their behef that the Secretary had the authority under the 1912 Act "to regulate hours and wavelengths of operation of stations when such action is necessary to prevent interference detrimental to the public good." N.Y. Times, March $25,1923, \S 2$, at 5 , col. 5 .

36. E. BARNOUW, supra note 22, at 121-22.

37. NBC v. United States, 319 U.S. 190, 211 (1943).

38. 12 F.2d 614 (N.D. Ill. 1926).

39. E. BARNouw, supra note 22 , at 189.

40. Federal Regulation of Radio Broadcasting, 35 Op. Att'y Gen. 126 (1926).

41. NBC v. United States, 319 U.S. at 212.

42. Id.

43. Ch. 169, 44 Stat. 1162 (1927), repealed, 48 Stat. 1102 (1934).

44. Id. $\$ 3$. 
tion power and hours of operation, ${ }^{45}$ and to issue, renew, and modify broadcast licenses if the public "interest, convenience, or necessity" would thereby be served. ${ }^{46}$

Seven years later, desiring to centralize the regulation of the telephone, telegraph, and broadcasting industries, ${ }^{47}$ Congress passed the Communications Act of $1934 .{ }^{48}$ This Act repealed the $1927 \mathrm{Act}^{49}$ and replaced the Federal Radio Commission with the Federal Communications Commission. ${ }^{50}$ The Act made little substantive change in broadcast regulation, however, as Congress retained most of the provisions of the 1927 Act, imcluding the "public convenience, interest, or necessity" language. ${ }^{51}$ It is this language that gave rise to the fairness doctrine.

\section{B. The Fairness Doctrine}

The FCC first enunciated the fairness doctrine, a policy mandating a balanced coverage of important public issues, in its 1949 report on Editorializing by Broadcast Licensees. ${ }^{52}$ The doctrine, as codified ten years later in an amendment to section 315(a) of the Communications Act of $1934,,^{53}$ consists of two basic requirements. The first, rarely a subject of litigation, ${ }^{54}$ is that the broadcaster must devote a reasonable amount of broadcast time to the discussion of controversial issues of public importance. ${ }^{55}$ The second requirement, probably the most con-

45. Id. §§ 4(b), 4(c).

46. Id. $\S 9$.

47. FCC v. Pottsville Broadcasting Co., 309 U.S. 134, 137 (1940); Simmons, The Fairness Doctrine: A Contemporary Definition, 29 FED. COM. B.J. 207, 237 (1976); OPTIONS PAPERS, supra note 4 , at 127. 1978)).

48. Ch. 652, 48 Stat. 1064 (1934) (current version at 47 U.S.C. $§ \S 151-609$ (1976 \& Supp. II

49. 48 Stat. 1102 (1934).

50. 47 U.S.C. $\S 151$ (1976).

51. Id. $\$ 303$.

52. 13 F.C.C. 1246 (1949). Based on the "public interest, convenience, or necessity" language of the 1927 and 1934 Acts, this doctrine can be traced to FRC and FCC decisions from the early days of broadcast regulation. See notes 55,57 infra.

53. Pub. L. No. 86-274, 73 Stat. 557 (1959). For the view that this amendinent was not intended as a ratification of the fairness doctrine, see Robinson, The FCC and the First Amendment: Observations on 40 Years of Radio and Television Regulation, 52 MiNN. L. REv. 67, 134 (1967).

54. The FCC has found a broadcasting station to have violated this requirement only once. Representative Patsy Mink (WHAR), 59 F.C.C.2d 987 (1976). For an equally rare discussion of the licensee's obligations under this requirement, see Comment, Enforcing the Obligation to Present Controversial lssues: The Forgotten Half of the Fairness Doctrine, 10 HARv. C.R.-C.L. L. REv. 137 (1975).

55. Red Lion Broadcasting Co. v. FCC, 395 U.S. 367, 377 (1969); Editorializing by Broadcasting Licensees, 13 F.C.C. at 1249. This obligation on the part of the hicensee can be traced to United Broadcasting Co., 10 F.C.C. 515, 517 (1945), in which the Commission held that the broadcaster has the duty "to be sensitive to the problems of public concern in the community and to inake sufficient time available . . . for full discussion thereof." 
troversial element of broadcast regulation today, ${ }^{56}$ is that this coverage must be balanced: if the broadcaster presents one viewpoint on an issue, it inust afford a reasonable opportunity for the presentation of opposing viewpoints. ${ }^{57}$ This second requirement applies only to the overall pattern of programming on an issue, ${ }^{58}$ and not to individual programming decisions. Thus, there is no requirement that the various viewpoints on an issue be presented on the same program, or even on the saine day, so long as overall balance is achieved..$^{59}$

When a licensee presents only one viewpoint on an issue, it undertakes an affirmative obligation to encourage the presentation of opposing viewpoints. ${ }^{60}$ Often, this duty can be discharged througlı a simple invitation to responsible members of the public to request air time. ${ }^{61}$ If no acceptable representative of an opposing viewpoint comes forward, the licensee must take a inore active role in soliciting a spokesman, ${ }^{62}$ at its own expense if no paid sponsorship can be found..$^{63}$

In determining whether these requirements have been met, the standard used by the FCC is one of reasonableness and good faith. ${ }^{64}$ The Commission is not to substitute its judgment for that of the licen-

56. D. Pember, Mass Media Law 417 (1977).

57. Red Lion Broadcasting Co. v. FCC, 395 U.S. at 377 ; Editorializing by Broadcast Licensees, 13 F.C.C. at 1251 . This obligation is usually thought to have originated with Mayflower Broadcasting Co., 8 F.C.C. 333, 340 (1940) ("as one licensed to operate in a public domain the licensee has assumed the obligation of presenting all sides of inportant public questions, fairly, objectively and without bias"). Its roots, however, can be traced back to two earlier decisions Inade by the Federal Radio Commission: Great Lakes Broadcasting Co., 3 F.R.C. Ann. Rep. 32, 33 (1928-29) ("In so far as a program consists of discussion of public questions, public interest requires anple play for the free and fair competition of opposing views"), and WEVD, 2 F.R.C. Ann. Rep. 154, 155 (1928) (programining "Inust, of course, comply with the requirements of the law and inust be conducted with due regard for the opinions of others").

58. Editorializing by Broadcasting Licensees, 13 F.C.C. at 1250 .

59. The balance contemplated need only be achieved over a reasonable period of time. Robinson, supra note 53, at 135 . The broadcaster cannot, however, look to other stations for this balance. Applicability of the Fairness Doctrine in the Handling of Controversial Issues of Public Importance, 40 F.C.C. 598, 606 (1964) [hereinafter cited as Fairness Doctrine Primer].

60. Fairness Doctrine Priner, supra note 59, at 605. If there are a variety of viewpoints on the issue discussed, not all need to be aired. A representative sampling of the viewpoints will satisfy the fairness doctrine. The Handling of Public Issues Under the Fairness Doctrine and the Public Interest Standards of the Communications Act, 48 F.C.C.2d I, 15 (1974) [hereinafter cited as Fairness Report].

61. There is "no single group or person entitled as a matter of right to present a viewpoint differing from that previously expressed on the station." Cullman Broadcasting Co., 40 F.C.C. 576,577 (1963). Thus, the broadcaster inay reject a request for air time by a particular person or group solely on the basis of inappropriateness, since it is the viewpoint, not the speaker, that is important to the fairness doctrine.

62. Fairness Report, supra note 60, at 13-14. This can be done, for exanple, by writing to persons or groups known or likely to hold such opposing viewpoints, and inviting thein to air their views.

63. Red Lion Broadcasting Co. v. FCC, 395 U.S. at 377.

64. Editorializing by Broadcast Licensees, 13 F.C.C. at 1251-52. 
see, ${ }^{65}$ which retains primary discretion over such areas as whether a controversial issue has been addressed, what points of view have been or should be presented under what programming format, and who should serve as spokesinan for those viewpoints. ${ }^{66}$ Only if the broadcaster's decisions are found to be unreasonable, arbitrary, or in bad faith are they to be overturned. ${ }^{67}$

When the FCC determines that a broadcaster has violated the fairness doctrine, ${ }^{68}$ the inost common sanction that it imposes is a simple order compelling the presentation of opposing viewpoints. ${ }^{69}$ Other, more extreme measures are rarely used: the FCC has denied only one license renewal on fairness doctrime grounds, ${ }^{70}$ and has revoked no license due to such a violation.

The constitutional validity of this regulatory scheme was challenged in 1969 in Red Lion Broadcasting Co. v. FCC. ${ }^{71}$ Red Lion involved an attack by a broadcaster, the Reverend Billy Hargis, on the character of Fred J. Cook, the author of a book entitled GoldwaterExtremist on the Right. When Cook learned of the broadcast, he demanded air time from the radio station involved so that he could reply to the attack. ${ }^{72}$ The station refused, and Cook sued to compel the provision of the air time requested. ${ }^{73}$

The Supreme Court upheld the statutory and constitutional validity of the FCC rules. ${ }^{74}$ This conclusion was based on a two-step analysis. First, the Court held that "the fairness doctrime and its component

65. Fairness Doctrine Primer, supra note 59, at 599.

66. Editorializing by Broadcast Licensees, 13 F.C.C. at 1251.

67. Public Media Center v. FCC, 587 F.2d 1322, 1328-32 (D.C. Cir. 1978).

68. This eventuality is not common. Of the 5,272 fairness doctrine complaints and inquiries filed in 1979, the FCC referred only 28 to the broadcaster for reply, and found against the licensee im only five cases, or 0.095 percent of the total. Letter from Arthur L. Ginsburg, Chief of the Complaints and Compliance Division, Broadcast Bureau, Federal Communications Coinınission (May 22, 1980) (on file with the California Law Review) [hereinafter cited as FCC Letter].

69. The Handling of Public Issues Under the Fairness Doctrine and the Public Interest Standards of the Communications Act, 58 F.C.C.2d 691,710 (1976) [lereinafter cited as $2 d$ Fairness Report]; Schneyer, An Overview of Public Interest Law Activity in the Communications Field, 1977 WIS. L. REV. 619, 669.

70. Brandywine-Main Line Radio, Inc. v. FCC, 473 F.2d 16 (D.C. Cir. 1972). Even then, misrepresentations made by the licensee provided an independent basis for the denial. Id. at 5052.

71. 395 U.S. 367 (1969). The Red Lion decision upheld only the personal attack and editorializing components of the faimess doctrine, 47 C.F.R. $\$ \$ 73.123,73.1920$ (1979). 395 U.S. at 396. Thus, the constitutionality of the regulations concerning the coverage of important issues has not yet been established. The Red Lion decision, however, was broadly written, and could be easily extended to cover this aspect of the fairness doctrine as well. See notes 82-84 and accompanying text infra.

72. This demand was based on the FCC rules on personal attacks, presently codified at 47 C.F.R. $\$ \S 73.123,17.1920$ (1979).

73. Both the FCC and the court of appeals found for Cook. 395 U.S. at 372-73.

74. Id. at $400-01$. 
personal attack and political editorializing regulations are a legitimate exercise of congressionally delegated authority" under the 1934 Act. $^{75}$ This holding was based both on the Commission's mandate to regulate broadcasting im a manner consistent with the "public convenience, imterest, or necessity"76 and on section 315 of the Act, as amended im 1959.77 The Court then held that the regulations "do not violate the First Amendment."78 Starting from the premise that "[a]lthough broadcastimg is clearly a medium affected by a First Amendment interest, . . . differences im the characteristics of the new media justify differences in the First Amendment standards applied to them,"79 the Court held that the physical scarcity inherent in the broadcast spectrum justifies the imposition of the fairness doctrine. Due to this scarcity, the Court said, "an unabridgeable First Amendment right to broadcast comparable to the right of every individual to speak, write, or publish" cannot validly be advanced, ${ }^{80}$ so that Congress is justified in regulating broadcasting in the public interest. This power to regulate the use of a scarce medium perunits Congress to require the licensed broadcaster to act as a fiduciary for those who cannot obtaim such access themselves, by presentimg a reasonable balance of opinion on issues of public importance. ${ }^{81}$

While the Red Lion decision directly concerned only the personal attack and political editorializing components of the fairness doctrine, and directly held only that a congressional innposition of those regulations was consistent with the first amendment, the language of the Court's opimion nnplies a much wider applicability. Most of the Court's opinion centers on the validity of the fairness doctrine as a whole, rather than on that of the specific components at issue. Thus, the Court's holding appears to have validated the doctrine in its entirety. ${ }^{82}$ Furthernore, the Court indicated in dictum that the fairness doctrine is not only consistent with the first amendment, but is the very essence of it. ${ }^{83}$ This notion was expanded in Columbia Broadcasting

75. Id. at 385 .

76. 47 U.S.C. \& 303 (1976).

77. Id. §315(a), as amended by Pub. L. No. 86-274, § 1, 73 Stat. 557 (1959).

78. 395 U.S. at 396.

79. Id. at 386.

80. Id. at 388 .

81. Id. at 389.

82. Several lower courts have so interpreted Red Lion. See, e.g., Larus \& Brother Co. v. FCC, 447 F.2d 876, 882 (4th Cir. 1971). But see American Sec. Council Educ. Found. v. FCC, 607 F.2d 438, 443 n.13 (D.C. Cir. 1979).

83. In the words of the Court, "[i]t is the right of the public to receive suitable access to social, political, esthetic, moral, and other ideas and experiences which is crucial here. That right may not constitutionally be abridged either by Congress or by the FCC." 395 U.S. at 390 (dictum). 
System, Inc. v. Democratic National Committee, ${ }^{84}$ and forms a major controversy in first amendment theory.

\section{Congressional Repeal of the Fairness Doctrine}

In the years since the Red Lion decision, several attempts have been made to repeal the fairness doctrine. Administrative repeal has been blocked by the mandate of section 315(a) of the Communications Act, ${ }^{85}$ which the Supreme Court has interpreted as codifying the fairness doctrine. ${ }^{86}$ Thus, the center of focus has shifted to the Legislature. Congress has considered several bills that would repeal the fairness doctrine. ${ }^{87}$

These bills have had three general bases. The first is the widespread feeling that, Red Lion notwithstanding, the fairness doctrine is unconstitutional. ${ }^{88}$ This feeling is based, in turn, on the probability that the doctrine inhibits, rather than promotes, protected speech, ${ }^{89}$ and on the fear that the doctrine unight provide the government with an opportumity for conscious repression of speech..$^{90}$ The second basis for the reforin bills is the belief that teclinological change, particularly the growth of cable television, has made the doctrine obsolete. ${ }^{91}$ The inultiplicity of voices created by this new technology may be sufficient to provide the desired diversity of viewpoints. The third basis for repeal is the perception that enforcement of the doctrine is not worth its cost, both in terms of out-of-pocket expenses ${ }^{92}$ and in terins of an inhibitimg effect on speech. In fact, the fairness doctrine is rarely enforced; ${ }^{93}$ thus, the government might more productively apply its energies in other ac-

84. 412 U.S. 94 (1973).

85. 47 U.S.C. § $315(a)$ (1976).

86. Red Lion Broadcasting Co. v. FCC, 395 U.S. at 380-82.

87. E.g., S. 2, 94th Cong., 1st Sess., 121 CoNG. REc. 211 (1975); S. 22, 95th Cong., 1st Sess., 123 CoNG. ReC. 529 (1977); S. 622, 96th Cong., 1st Sess., 125 CoNG. ReC. S2525 (daily ed. Mar. 2, 1979).

88. See, e.g., Proposed Amendments to the Communications Act of 1934: Hearings on S. 2, S. 608, and S. 1178 Before the Senate Comm. on Commerce, 94th Cong., 1st Sess. 17 (1975) (statement of Sen. Proxmire) [hereinafter cited as 1975 Hearings]; Barrow, The Equal Opportunities and Fairness Doctrines in Broadcasting: Pillars in the Forum of Democracy, 37 U. CIN. L. REv. 447 (1968).

89. E.g., Proposed Amendments to the Communications Act of 1934: Hearings on S. 611 and S. 622 Before the Subcomm. on Communications of the Senate Comm. on Commerce, Science, and Transportation, 96th Cong., 1st Sess. 2628-29 (1979) (statement of Sen. Proxmire) [hereinafter cited as 1979 Hearings].

90. See, e.g., 1977 Hearings, supra note 5, at 9-10 (statement of Sen. Proxmire).

91. Van Deerlin, Introduction to Symposium-Communications Regulation, 69 Callf. L. REv. 446, 449 (1980).

92. See Simmons, The "Unfaimess Doctrine"-Balance and Response Over the Airwaves, 1 Сомm/ENt 1, 33 n.137 (1977).

93. See note 68 supra. 
tions promotive of program diversity. ${ }^{94}$

While no bill proposing the repeal of the fairness doctrine has yet been passed, the probability of such an enactment in the future is increasing. Although strenuously opposed by some, ${ }^{95}$ repeal of the fairness doctrine has gamed the broad support of those in the broadcast industry ${ }^{96}$ and, lately, of the FCC itself. ${ }^{97}$ This Comment posits that such a bill will be enacted into law in the couning years.

II

\section{PreliminaRy CONSIDERATIONS}

The first ainendment's guarantee of freedom of the press has acted for nearly 200 years to himit government mvolvement in and interference with the news gathering and disseinmation functions of the print medium. ${ }^{98}$ The broadcast mediuin, having developed almost entirely within the last sixty years, does not share this history of constitutional protection. ${ }^{99}$ Broadcasting has been accorded equal stature with the print medium in at least some first amendment areas. ${ }^{100}$ But the courts have consistently held that, because of the unique nature of the broadcast medium, broadcasting presents special problems and therefore warrants separate consideration in many first amendment questions, ${ }^{101}$ including the degree of legislative involvement in the editorial process. ${ }^{102}$

The plaintiff in a court action attempting to inpose content regulation on the broadcast industry after repeal would argue that broadcasting deserves special treatment even in the absence of legislative involvement. This assertion, however, would not enjoy the presumption of validity that accompanied the fairness doctrine. All statutory and administrative enactments are presumed by the courts to be consti-

94. See notes 313-19 and accompanying text infra.

95. See, e.g., 1977 Hearings, supra note 5, at 73-76 (statement of Ralph M. Jennings).

96. Krasnow \& Robb, Telecommunications and the 94th Congress: An Overview of Major Congressional Actions, 29 FED. COM. B.J. 117, 162 (1976).

97. See 1977 Hearings, supra note 5, at 20, 25 (statement of Charles D. Ferris, Chairman of the FCC, to the effect that the FCC supports elimination of the fairness doctrine in radio where there are many independent stations and, more tentatively, favors a gradual approach to repeal in television).

98. See, e.g., New York Times Co. v. United States, 403 U.S. 713 (1971).

99. See Schmidt, Pluralistic Programming and Regulation of Mass Communications Media, in COMMUNICATIONS FOR TOMORROW 197 (G. Robinson ed. 1978).

100. See, e.g., Rosenbloom v. Metromedia, Inc., 415 F.2d 892 (3d Cir. 1969), affd, 403 U.S. 29 (1971) (libel).

101. Joseph Burstyn, Inc. v. Wilson, 343 U.S. 495, 503 (1952).

102. Compare, e.g., Red Lion Broadcasting Co. v. FCC, 395 U.S. 367 (1969) with Miami Herald Publishing Co. v. Tornillo, 418 U.S. 241 (1974). 
tutional. $^{103}$ Thus, a broadcaster challenging a legislated fairness requirement on constitutional grounds must meet the burden of proof: in order to prevail, it inust demonstrate to the court that its position is correct. If there were no underlying legislative or administrative enactment, however, the burden would shift. Under these circumstances the party attempting to establish a fairness requirement must carry the burden of proof; it must show that the status quo, the absence of content regulation, is unconstitutional. Thus, the plaintiff must meet a higher standard of proof in order to impose content regulation on constitutional grounds than was necessary to legitimize the congressionally imposed fairness doctrine.

\section{A. Standing}

Since the plaintiff's claim in the hypothetical case centers on a question of federal constitutional law, he could bring it in federal court. Before a federal court will hear the claim, however, the plaimtiff inust show that he has standing to bring the suit. Standing is a complex doctrine $^{104}$ of justiciability ${ }^{105}$ involving both constitutional and prudential limitations on complainants' access to the federal courts. ${ }^{106}$ The purpose of the doctrine is to "limit the business of federal courts to questions presented in an adversary context and in a form historically viewed as capable of resolution through the judicial process," 107 and thus to avoid the deternination of ill-defined, hypothetical, or abstract questions of constitutional law. ${ }^{108}$

Where the plaintiff does not rely on a statutory grant of standing, the standing requirement has two components. The first is the requirement that the plaintiff allege "such a personal stake in the outcoine of the controversy as to assure that concrete adverseness upon which the court so largely depends for illumination of difficult constitutional questions." 109 This requirement, known as the "injury-in-fact" test, looks not to the issue or issues that the plaintiff wishes to have adjudicated, but to the plaintiff himself. ${ }^{110}$ Thus, in order to have standing,

103. C. Sands, Sutherland's Statutory Construction, vol. 1A, \$31.02 (administrative) (4th ed. 1972), vol. 2A, §45.11 (statutory) (4th ed. 1973).

104. One commentator has described standing as one of the "most amorphous [concepts] in the entire domain of public law." Hearings on S. 2097 Before the Subcomm. on Constitutional Rights of the Senate Comm. on the Judiciary, 89th Cong., 2d Sess. 498 (1966) (statement of Prof. Paul A. Freund).

105. Flast v. Cohen, 392 U.S. 83, 95 (1968).

106. Warth v. Seldin, 422 U.S. 490,498 (1975).

107. Flast v. Cohen, 395 U.S. at 95.

108. Id. at 100 .

109. Baker v. Carr, 369 U.S. 186, 204 (1962).

110. Jenkins v. McKeithen, 395 U.S. 411,423 (1969) (opinion of Marshall, J.); Flast v. Cohen, 392 U.S. at 99. 
the plaintiff himself must have suffered an mjury to a cognizable interest as a result of the challenged action. ${ }^{111}$

The injury alleged need not be economic in character. The courts have recognized several noneconomic injuries for the purpose of conferring standing. ${ }^{12}$ Moreover, there is no requirement that the injury alleged be peculiar to the plaintiff: it may be a harm shared by a large number of people, ${ }^{113}$ so long as the plaintiff himself is one of those so harmed. ${ }^{114}$

In the hypothetical case posited here, the plaintiff would be a person or group allegedly harmed either by a general lack of public issue programming or by a failure to present a balanced presentation of the issues covered. The injury claimed would be to the plaintiff's alleged first amendment right to a fair and balanced presentation of opposing viewpoints on such issues. ${ }^{115}$ This harm is sufficient to satisfy the injury-in-fact test. Although noneconomic in nature, the plaintiff's injury is concrete and substantial: It is the deprivation of the balanced programming necessary for informed decisionmaking. It is not a "general grievance": it centers on a specific instance of a broadcaster's failure to provide the desired programming balance. There is thus a concrete factual setting for the determination of the first amendment issues presented. ${ }^{116}$

The major broadcasting case treating the standing issue is Office of Communication of the United Church of Christ v. FCC. ${ }^{117}$ In that case, the court permitted the Office of Communication to intervene in a radio station license renewal proceeding on behalf of many residents of Jackson, Mississippi. The court found standing based on the unique position of the histener in ensuring that broadcasters operate in the pubhic interest. As the ultimate owners of the airwaves, the listeners' interest in the proper use of the broadcast spectrum is direct. They are ultimately responsible for the quality of broadcast programming, and thus share a duty to take an active role in the determination of program

111. Warth v. Seldin, 422 U.S. at 499; Sierra Club v. Morton, 405 U.S. 727, 734-35 (1972).

112. See Association of Data Processing Serv. Orgs., Iuc. v. Camp, 397 U.S. 150, 153-54 (1970), and cases cited therein.

113. This proposition is limited, however: a "general grievance," shared in substantially equal measure by all or a large class of citizens may not be sufficient aloue to warrant a finding of standing. Warth v. Seldin, 422 U.S. at 501.

114. Id.

115. While standing does not depend on the merits of the case, it may rest on the nature and source of the claim asserted. Id.

116. Once an individual injury is found, the plaintiff may support his claim by invoking the general public interest. See id. at 501 (citing Sierra Club v. Morton, 405 U.S. at 737). In fact, one court has stated that in a broadcasting case "standing is accorded to persons not for the protection of their private interest but only to vindicate the public intercst." Office of Communication of The United Church of Christ v. FCC, 359 F.2d 994, 1001 (D.C. Cir. 1966).

117. 359 F.2d 994 (D.C. Cir. 1966). 
content. ${ }^{118}$ Moreover, listeners, as the consumers of broadcast programming, may be the only parties with a sufficient interest to challenge program deficiencies.119 Thus, in light of the "practical and functional" nature of the standing doctrine, the court could find "no reason to exclude those with sucli an obvious and acute concern as the histening audience." 120

Although United Church of Christ involved standing before the FCC, the same factors sliould apply in deciding wlietlier there is standing before a court. The histeners' interest in the use of the airwaves is as substantial when brought before a court as it is when brought before an agency. The same is true with regard to their unique relationship with the broadcast licensees. And when the listeners' interest is impaired, the degree of that hann is not affected by the nature of the body to which they must apply for redress of grievances. ${ }^{121}$ Thus, the plaintiff's claim should pass the injury-in-fact test.

The second component of the standing question is the requireinent that "the interest sought to be protected by the coinplainant [be] arguably within the zone of interests to be protected or regulated by the . . . constitutional guarantee in question."122 This requires a logical nexus between the asserted status of the plaintiff and the constitutional claim that he seeks to have adjudicated. ${ }^{123}$ Thus, in this case, the plaintiff must allege a sufficient colmection between his status as a broadcast listener and a specific constitutional guarantee, and then between that guarantee and the actions challenged.

The hypothetical plaintiff here could estabhsh this nexus easily. The connection between his status as a broadcast histener and the asserted constitutional guarantee of a balanced presentation of viewpoints on important public issues by broadcasters clearly exists, since histeners are directly affected by that balance. The guarantee of balanced presentations is, in turn, connected with the actions challenged,

118. Id. at 1003 (quoting FCC, Television Network Program Procurement, H.R. Rep. No. 281, 88th Cong., 1st Sess. 20 (1963)).

119. 359 F.2d at 1004-05:

Unless the listeners-the broadcast consumers-can be heard, there may be no one to bring programming deficiencies or offensive overcominercialization to the attention of the Commission in an effective manner. By process of elimination, those seeking intervention in a Commission proceeding are likely to be the only ones "Iraving a sufficient interest" to clrallenge a renewal application.

120. Id. at 1002.

121. Justice Stewart, in his concurring opinion in CBS v. Democratic Nat'l Comin., 412 U.S. 94 (1972), recognized the importance of these factors when he stated that "the public interest in broadcasting lias been recognized as a rationale for liberalized standing on the part of listener groups in Commission licensing proceedings." Id. at 136-37 (Stewart, J., concurring).

122. Association of Data Processing Serv. Orgs., Inc. v. Camp, 397 U.S. at 153.

123. Flast v. Cohen, 392 U.S. at 102. See also Jenkins v. McKeithen, 395 U.S. at 423 (opinion of Marsliall, J.). 
since by failing to provide the desired balance in programming the broadcaster directly calls into question that guarantee. Thus, both components of the standing test would be satisfied, and the plaintiff would have standing to bring his claim before the court.

\section{B. State Action}

Before the court can reach the merits of the plaintiff's allegations, it must find that the actions of the broadcaster in failing to provide the desired coverage are equivalent to the actions of the state. The first amendment restrains only government action. ${ }^{124}$ Thus, if the challenged actions are entirely private in nature, the amendment cannot be invoked in a lawsuit challenging thein. The courts, however, have found state action in inany situations in which at first glance it appears as if only private action is imvolved. Whether state action exists $\mathrm{m}$ an ostensibly private activity depends on "whether there is a sufficiently close nexus between the State and the challenged action of the regulated entity so that the action of the latter may be fairly treated as that of the State itself." 125 There is no precise formula for deciding whether such a relationship exists. "Only by sifting facts and weighing circumstances can the nonobvious involvement of the State in private conduct be attributed its true significance." 126

The issue of state action in broadcasting has been addressed by members of the Supreine Court in only one case, Columbia Broadcasting System, Inc. v. Democratic National Committee. ${ }^{127}$ In $C B S$, certain private organizations attempted to buy television advertising time in order to present their views on various public issues. The broadcasters involved refused to sell thein any air time. The organizations then sued the broadcasters, alleging that their first amendment right of access to the broadcast medium had been violated. Only five of the Justices considered the state action issue. Chief Justice Burger, in an opinion joined by Justices Stewart and Relinquist, with Justice Stewart also writing a concurring opinion, ${ }^{128}$ found no state action; Justice Brennan, joined by Justice Marshall, came to the opposite conclusion, finding the requisite state action. ${ }^{129}$

Chief Justice Burger's opinion, ${ }^{130}$ although grounded in part on

124. Civil Rights Cases, 109 U.S. 3,13 (1883).

125. Jackson v. Metropolitan Edison Co., 419 U.S. 345, 351 (1974).

126. Burton v. Wilmington Parking Auth., 365 U.S. 715,722 (1960).

127. 412 U.S. 94 (1973).

128. Id. at 132 (Stewart, J., concurring).

129. Id . at 170 (Brennan, J., dissenting). Justice Douglas, though not reaching the state action issue, implied that he would find state action if the question were properly before the Court. 412 U.S. at 148 (Douglas, J., concurring in judgment).

130. 412 U.S. at 114-21 (opinion of Burger, C.J.). 
the FCC's role in the specific actions complamed of ${ }^{131}$ and on the level of government regulation of the broadcast industry, ${ }^{132}$ rested primarily on the observation that the regulatory system established by the Communications Act attempts to preserve the imdependence of the broadcast journalist to the greatest extent possible. ${ }^{133}$ Concludimg that a finding of state action would allow judicial scrutiny of most of the broadcaster's journalistic decisions, and would therefore destroy that independence, ${ }^{134}$ he found that no state action was involved.

This line of analysis is fiawed for two reasons. First, it places too great an emphasis on the legislature's intent to preserve a high level of journalistic discretion, since that intent might have been a major factor in bringing about the unconstitutional result alleged. Congress may have exceeded its constitutional autliority im granting to broadcasters such a high level of journalistic discretion. The courts should retain the power to decide that question. Second, it confuses tlie relationship between the issue of state action and the merits of the case. State action sliould be a preliminary issue, determining only whether the first amendment applies to the actions im question, not to the manner im which it may apply. The extent of the broadcaster's proper journalistic discretion goes to the heart of the first amendment issue presented, and should be addressed only if state action in the exercise of that discretion is found.

Justice Stewart, in his concurring opmion, ${ }^{135}$ also addressed the issue of state action. Equating a finding of state action to holding that "private broadcasters are Government," 136 lie concluded that sucli a finding would eliminate all first amendment protections for broadcasters. Seemg this prospect as a "friglitening specter,"137 lie declined to find any state involvement.

This position is also in error, both in its basis and in its conclusion. First, a finding of state action does not convert a previously private actor into government per se. It determines only that its actions regard-

131. The Chief Justice concluded that "the Commission las not fostered the licensee policy challenged here; it has simply declined to command particular action because it fell within the area of journalistic discretion," 412 U.S. at 118, and therefore state action was not present.

132. 412 U.S. at 119-20. For a fuller discussion of this issue, see notes 153-54 and accompanying text infra.

133. The Chief Justice cited two provisions of the Act in specific support of this proposition: $\S 326$, prohibiting government interference with the broadcaster's free speech, and $\S 3(\mathrm{~h})$, mandating that broadcasters not be treated as common carriers. 412 U.S. at 116; $c f$. FCC v. Midwest Video Corp., 440 U.S. 689 (1979) (rejecting cable television public access regulations on the basis of $\$ 3(h))$.

134. 412 U.S. at 119.

135. Id. at 133-41 (Stewart, J., concurring).

136. Id. at 133 (emphasis in the original).

137. Id. 
ing limited areas of particular constitutional significance are so intertwined with those of the government that it cannot act if the government could not so act. It still remains, in all other senses, a private actor. ${ }^{138}$ Second, a finding of state action would not ehminate the broadcaster's first amendinent protections. Indeed, the court may find that the amendinent protects the challenged actions from government interference. By finding state action, the court merely estabhishes that it inust balance the parties' interests; it does not determine the outcoine of that balancing. ${ }^{139}$

Justice Brennan approached the state action issue more directly. He maintained that state action could be found in the combination of four characteristics of broadcasting: "the public nature of the airwaves, the governmentally created preferred status of broadcast hicensees, the pervasive federal regulation of broadcast programming, and the Commission's specific approval of the challenged broadcaster policy." 140

This approach to the state action issue is the nost promising. It has two distinct advantages over the approaches used by Chief Justice Burger and Justice Stewart. First, it does not confuse the merits of the case with the preliminary question of state action. ${ }^{141}$ Second, it recognizes that the Court should look at the relationship between the government and the private actor as a whole, ${ }^{142}$ rather than looking at each component of that relationship separately. ${ }^{143}$ If a court is to examine the nexus between the state and the actions of a private entity, it should do so on the basis of the cunnulative impact of the various state counections.

Based on this "cuinulative impact" approach, the court in the hypothetical case should find a sufficiently close nexus between the government and the actions of the private broadcaster in refusing to present a balanced coverage of important public issues to satisfy the state action requirement. The coinbination of four interrelated factors dictates this result. The first is the public ownership of the airwaves. Section 301 of the Cominunications Act ${ }^{144}$ declares that while private broadcasters are granted use of the elcctroinagnetic spectrum, ultimate

138. See id. at 181 (Brennan, J., dissenting).

139. See id. at 181 n.12.

140. Id. at 173 (Brennan, J., dissenting).

141. See text following note 134 supra.

142. This was the approach adopted in Burton v. Wilmington Parking Auth., 365 U.S. 715, 724 ("Addition of all these [factors] indicates that degree of state participation and involvement in discriminatory action which it was the design of the Fourtecnth Amendinent to condemn.").

143. In Jackson v. Metropolitan Edison Co., 419 U.S. 345 (1974), however, the Court looked at the various indicia of state action sequentially. This approach fails to recognize the complexity of many private actor-state relationships, and has been justifiably criticized. See, e.g., The Supreme Court, 1974 Term, 89 HARv. L. REv. 47, 148-50 (1975).

144. 47 U.S.C. $\& 301$ (1976). 
control and ownership rest in the United States. When the government permits a private party to use its property in such a way that the constitutional rights of others are imphicated, public ownership-evidencing some degree of government acquiescence in the actions complained of ${ }^{145}$-should be a strong indication of state action.

The second sign of state action is found in the "quasi-monopolistic" status of the broadcaster. ${ }^{146}$ For the term of its license, the broadcaster has within its locality the right to the exclusive use of its assigned wavelength. This privilege system, a product of the chaos of the 1920 's, ${ }^{147}$ clearly connects the action of the state with that of the private broadcaster, because the broadcaster derives its authority to act from the government. ${ }^{148}$

Jackson v. Metropolitan Edison Co., ${ }^{149}$ however, appears to contradict this conclusion. In Jackson the Supreme Court held that regardless of the fact that the state government had granted the defendant a local monopoly in the provision of electric power, Metropolitan's action im terminating Jackson's electrical service did not constitute state action for purposes of the due process clause of the fourteenth amendment. ${ }^{150}$ Jackson, however, is factually distinguishable. Metropohitan's monopoly status, although condoned by the government, did not depend on government regulation for its creation. Public utility companies such as Metropolitan, the Court noted, generally are natural monopohes, created by high threshold capital requirements and economies of scale. ${ }^{151}$ The broadcaster's monopoly status, on the other hand, is entirely a creature of the government. Without the licensing scheme of the Communications Act, broadcasting might not have advanced beyond its pre-1927 state, when several stations often used the same wavelength at the same time. ${ }^{152}$ Thus, a far closer relationship exists between the actions of the state and the monopoly status of the broad-

145. Justice Brennan drew a comparison between the actions of the networks in $C B S$ and those of the defendant in Burton v. Wilmington Parking Auth., 365 U.S. 715 (1960). 412 U.S. at 174-75 (Brennan, J., dissenting). In Burton, the plaintiff challenged the discrimimatory practices of a restaurateur on constitutional grounds. The Court found that state action was implicated in those practices, due in part to the fact that the state owned the building in which the restaurant was located. 365 U.S. at 725 .

146. See 412 U.S. at $175-76$ (Brennan, J., dissenting).

147. See notes $26-42$ and accompanying text supra.

148. "[W]hen authority derives in part from Government's thumb on the scales, the exercise of that power by private persons becomes closely akin, in some respects, to its exercise by the Government itself." American Communications Ass'n v. Douds, 339 U.S. 382, 401 (1950), quoted in CBS v. Democratic Nat'l Comm., 412 U.S. at 176 (Brennan, J., dissenting).

149. 419 U.S. 345 (1974).

150. The Court found that "there was [an] insufficient relationship between the cliallenged actions of [Metropolitan] and [its] monopoly status." Id. at 352.

151. Id. at $351 \mathrm{n} .8$.

152. See note 26 supra. 
caster than between state regulation of public utihities and the monopolization of that industry in each respective locality by a very few large companies. Its impact on the question of state action likewise should be greater.

The third factor is the unique regulatory relationship between the broadcaster and the government. ${ }^{153}$ Government regulation of broadcasting is inore pervasive than in any other industry, ${ }^{154}$ and affects nearly every aspect of the broadcaster's busmess. It extends far beyond the business regulations generally imposed on private enterprise; the hand of the government is in nearly every decision the licensee inakes. This involvement is additional evidence of state action.

The final indication of state action, and probably the most important, is the government's involveinent in the actions complained of. Before the Radio Act of 1927, no broadcaster had the power to control what was said over any wavelength, since the airwaves were open to anyone with the capability to broadcast. Under the 1927 and 1934 Acts, the broadcaster has only limited control over its assigned wavelength, as it has the duty to present a fair and balanced discussion of important public issues. By repealing the doctrine, however, Congress would take ultimate control over the broadcast medium away from the public, as represented by the government, and give it to a group of private monopolists, the broadcasters. Tlus, the government would give broadcasters a right-the right to speak over the airwaves-without a correlative duty to ensure that that right is exercised to the greatest public good.

Such a grant of power clearly implicates the government in the subsequent use of that power. ${ }^{155}$ By repealing the fairness doctrine, Congress would, in effect, give broadcasters the ability to exclude others from the opportunity to use the airwaves in exercise of their right to free speech. Congress inay not have the constitutional power to take such an action. The state action doctrine may not permit it to abandon its role in determining the proper balancimg of constitutional rights and duties in this area ${ }^{156}$ by delegating the power to make that balance to private parties. That delegation should not preclude judicial review of the balance that broadcasters strike.

153. See 412 U.S. at 176-77 (Brennan, J., dissenting).

154. See Business Executives' Move for Vietnam Peace v. FCC, 450 F.2d 642, $651-52$ (D.C. Cir. 1971), rev'd sub nom. CBS v. Denocratic Nat'I Comm., 412 U.S. 94 (1973). For example, the FCC must approve all volnntary transfers of broadcast stations, 47 C.F.R. $§ 73.3540$ (1979), and AM radio stations must obtain FCC approval merely to move their main studio location in many circumstances, $i d . \S 73.31$.

155. See generally Note, State Action: Theories for Applying Constitutional Restrictions to Privare Activity, 74 Colum. L. Rev. 656, 664 (1974).

156. Cf. The Supreme Court, 1974 Term, supra note 143, at 151 (1975) (discussing Jackson). 
Thus, based on the cumulative impact of the public ownership of the airwaves, the governmentally created and maintained quasi-monopohstic status of the broadcaster, the pervasive government regulation of the broadcast industry, and the involvement of the government in the specific broadcaster actions challenged, the court should find that the state action requirement has been satisfied.

\section{III}

\section{Judicial IMPOSITION OF CONTENT REGULATION AND THE FIRST AMENDMENT}

\section{A. Distinguishing Between the Print and Broadcast Media}

The courts have long embraced a "hands off" approach to newspaper and magazine content, ${ }^{157}$ and would be unlikely to reverse themselves now. Thus, if no constitutionally relevant distinction between the print and broadcast media exists, the plaintiff's goal would be diffcult to achieve even if the court finds state action in the broadcaster's refusal. Judicial imposition of content regulation on the broadcast mediuin would, by imphication, permit its extension to the print medium as well. It would enhance the plaintiff's chance of success, however, if a valid distinction can be drawn between the two media, because the court could then impose restrictions on broadcasters without affectimg the protected position of the print medium.

Regardless of whether or not they are constitutionally distimguishable, the print and broadcast inedia have always been perceived as different. ${ }^{158}$ In part, this has been due to the physical differences between the two, ${ }^{159}$ and to the status of broadcasting as a relative newcomer to the field of journalism. ${ }^{160}$ The inost significant factor in this popular distinction, however, has been the general perception of broadcastimg as an entertainment-oriented niedium. ${ }^{161}$ While entertainment programming is protected speech, ${ }^{162}$ it has never been considered to be at the core of the first amendment. ${ }^{163}$ Because of this perception of the broadcast inedium, content regulation of the broadcast inessage was

157. See, e.g., Miami Herald Publishing Co. v. Tornillo, 418 U.S. 241 (1974).

158. See, e.g., Bollinger, Freedom of the Press and Public Access: Toward a Theory of Partial Regulation of the Mass Media, 75 MiCH. L. REv. 1, 21 (1976); Bazelon, FCC Regulation of the Telecommunications Press, 1975 DuKe L.J. 213, 218.

159. Quite simply, one medium uses the spoken word while the other uses the printed word.

160. These distinctions are irrelevant to the first amendment status of the broadcast press. Whether a statement is spoken or written should have no effect on its protection by the first amendment, if in both cases it is protected speech. And while the broadcast medium may be a latecomer to the field of journalisin, it is now an important component of that profession. See Bazelou, supra note 158, at 220.

161. See id. at 219-20.

162. Citizens Comm. to Save WEFM v. FCC, 506 F.2d 246, 251 (D.C. Cir. 1974) (en banc).

163. Bazelon, supra note 158 , at 219. 
instituted and has been maintained without the protest that would accompany a similar imposition on the print inediuin. Indeed, broadcasters have done little to try to change this situation. ${ }^{164}$

Entertainment still commands a large proportion of the broadcast day. However, the status of broadcasting as an inforinative and an investigative mediuın has grown dramatically since 1921 . To a majority of Americans television is a major source of news and commentary. ${ }^{165}$ The professionalism of many broadcast journahists rivals that of even the best print journahists. Thus, while inany still see the broadcast inedium as different, that perception has no strong factual basis. The broadcast mediuin has become an important core coinponent of the press, and perceived differences between it and the print medium are not of constitutional relevance.

Three possible distinctions between the print and broadcast media, however, have gained at least some support in justifying the legislative and administrative iniposition of the fairness doctrine: the physical scarcity inherent in the use of the broadcast inedium, the greater impact of the broadcast message on the public's perception of public issues, and the public ownership of the airwaves themselves.

\section{Scarcity}

Of the rationales used in justifying the fairness doctrine, the physical scarcity inherent in the broadcast spectruin ${ }^{166}$ is the inost important, and is the only one clearly recognized by the Supreine Court. First enunciated in National Broadcasting Co. v. United States ${ }^{167}$ and later adopted as the basis for content regulation in Red Lion Broadcasting Co. v. $F C C,{ }^{168}$ scarcity is the only rationale relied on by the courts to distimguish between the print and broadcast inedia. ${ }^{169}$

164. Options Papers, supra note 4, at 65-67. Some broadcasters may even prefer content regulation to the vicissitudes of the market. Robinson, supra note 8, at 192 .

165. The results of a recent Roper Poll, reported by Senator Proxmire, indicate that $67 \%$ of the American public looks to television as a major source of news, compared to $20 \%$ for radio and $49 \%$ for newspapers (the total is more than $100 \%$ due to multiple answers). 1979 Hearings, supra note 89 , at 2628 .

166. While all resources are physically scarce in the sense that their supply is finite, the probabihty that the number of persons able to use a resource will become linited, given current consumption patterns, may be very low. It is only where present or anticipated usage entails sucl a limiting effect that scarcity becomes significant.

167. 319 U.S. at 216.

168. 395 U.S. at 388-89.

169. See, e.g., Brandywime-Main Line Radio, Inc. v. FCC, 473 F.2d 16, 43 (D.C. Cir. 1972), cert. denied, 412 U.S. 922 (1973). The extension of the fairness doctrine to cable television, 47 C.F.R. $\$ 76.209$ (1979), casts doubt on the scope of actual reliance on the scarcity rationale. The concept of plysical scarcity does not apply to cable television, because cable does not use the broadcast spectruin. Thus, if the fairness doctrine is to be held constitutional as apphied to cable television, an alternative justification must be advanced. 
While anyone with the means and desire to do so can publish, the scarcity argument runs, broadcasting is reserved for a select few. ${ }^{170}$ The broadcast spectrum is limited in size; ${ }^{171}$ thus, only a limited number of stations can operate at a given time without producing interference. Simce more people desire to broadcast than there are channels to accommodate them, those who procure broadcast licenses attain a governmentally sanctioned privileged position, unparalleled in the print medium, from which they can present their views. The broadcaster's advantage, however, is not absolute: in exchange for the monopoly that it enjoys over a certaim wavelength, the broadcaster undertakes an affirmative obligation to use that wavelength $\mathrm{m}$ the public imterest, covering important public issues and presenting all viewpoints on the issues discussed. ${ }^{172}$

Several of the critics of content regulation ${ }^{173}$ have maintained that physical scarcity is a meaningless concept, citmg the unfilled spectrum positions presently available ${ }^{174}$ and the greater number of broadcast stations than newspapers operating in the United States. ${ }^{175}$ However, it is the inherent scarcity of the broadcast spectrum, not its present state of use, that is operative here. Present levels of spectrum congestion are largely irrelevant ${ }^{176} \mathrm{~m}$ this analysis, since the potential for use is still significantly limited. Thus, while there are many speakers, the nuniber of viewpoimts represented is not as large. ${ }^{177}$

170. H. Geller, The Falrness Doctrine in Broadcasting: Problems and Suggested COURSES OF ACTION 8 (1973).

171. Presently, radio operates from $88 \mathrm{Mc} / \mathrm{s}$ to $108 \mathrm{Mc} / \mathrm{s}$ (FM), 47 C.F.R. $\$ 73.201$ (1979), and from $535 \mathrm{kHz}$ to $1605 \mathrm{kHz}$ (AM), id. $\S 73.1$. All FM stations are required to be at least 0.1 $\mathrm{Mc} / \mathrm{s}$ apart, id. $\S 73.201$, and all AM stations $10 \mathrm{kHz}$ apart, $i d . \& 73.3$. Other parts of the radio spectrum are reserved for other uses, such as mihitary, aviation, common carrier, and amateur radio communication. Red Lion Broadcasting Co. v. FCC, 395 U.S. at 397-98. For a discussion of proposals to expand the broadcast spectrum and reduction in the space required between stations, see text accompanying notes 315-16 infra.

172. See Red Lion Broadcasting Co. v. FCC, 395 U.S. at 389.

173. E.g., Simmons, supra note 92, at 43-44; Robinson, supra note 53, at 152-53.

174. Robimson, supra note 53, at 158.

175. E.g., 1975 Hearings, supra note 88, at 9-10 (statement of Sen. Proxmire).

176. If the spectrum were so broad that full use was improbable, scarcity would not be a serious problem. This is the situation with newspapers, for example. One's ability to print is inherently limited by the availability of such resources as papor and ink. This limitation, however, has not proved to be a barrier to entry into the newspaper market, since it has not yet been reached and is not likely to be reached. By contrast, scarcity in the broadcast spectrum has proved to be a real barrier. See Red Lion Broadcasting Co. v. FCC, 395 U.S. at 398 \& n.25, 399. See also H. GeLLER, supra note 170 , at 8.

177. A similar argument can be made with regard to newspapers, due to the increasing prevalence of newspaper chains and the influence of the AP and UPI wire services. See Bollinger, supra note 158, at 15. While certainly accurate to some extent, it does not establisli a distinction between the media; rather, it establishes a similarity. Moreover, it does not recognize the breadth of the print media: magazines, books, and other means of printed communication unust be considered as well. One commentator has even suggested that the proper comparison is not between 
The scarcity rationale, however, is unconvincing. Technological advancements in the broadcast industry refute the notion of physical scarcity. The advent of cable and direct satellite broadcasting has greatly expanded the number of broadcast channels available, with even greater expansion promised for the future. ${ }^{178}$ A single coaxial cable, for example, can presently carry as many as fifty-four television stations, ${ }^{179}$ and the expected use of optical fibers for broadcast purposes in the near future should provide an even greater carrying capacity. ${ }^{180}$ The only scarcity associated with such a system is the limit on the number of stations that a given cable can transmit. This problem can be easily eliminated through the use of multiple cables. Likewise, broadcast satellites, with their ability to transmit thousands of messages simultaneously, ${ }^{181}$ promise to revolutionize the broadcast industry. ${ }^{182}$

While the economic future of these new technologies remains debatable, ${ }^{183}$ their impact on the concept of physical scarcity is clear. They present to anyone with the ineans and the desire to broadcast the opportunity to do so. They therefore eliminate any distinction between the physical scarcity found in broadcasting and that found in the print medium.

The existence and promise of these technologies, however, does not mean that the concept of scarcity is without practical significance in the broadcast industry. The elimination of physical scarcity will not eliminate the problem of economic barriers to entry into broadcasting. ${ }^{184}$ The days of the hundred-watt radio station operated froin atop one's busmess are gone. ${ }^{185}$ Today, the entry cost in the broadcast mar-

operating broadcast stations and newspapers, but between spectrum positions and printing presses. T. EMERSON, THE SYSTEM OF FrEe EXPRESSION 662-71 (1970).

178. For a discussion of the advances in broadcast technology, and their promise for the future, see Baer, Telecommunications Technology in the 1980's, in Communications for ToMORROW, supra note 99 , at 61-108.

179. See, e.g., In-Sync, BroAdCASTing, Jan. 14, 1980, at 83.

180. Baer, supra note 178 , at 1077.

181. Id. at 95. With the expected use of NASA's Space Shuttle in future years, it will be feasible to launch satellites "capable of relaying 100,000 voice circuits or 100 television channels with multiple spot beams," permitting both localization and variety. $I d$. at 94 .

182. Many see these technologies as a promised escape from the "vast wasteland" of modernday broadcast programming. See note 268 infra.

183. See, e.g., N. Johnson, How to Talk Back to Your Television Set 152-55 (1967); Baer, supra note 178 , at $96-97$.

184. In this context, "economic scarcity" refers to the limitation of the number of persons in a given business due to economic factors such as a high cost of entry or significant economies of scale. Other commentators have used this term for another purpose: to describe the ever-present situation in which demand for a resource, if it is conveyed without cost or at a lost cost, exceeds its supply. This situation has been found to exist in broadcast licensing. See, e.g., Coase, The Federal Communications Commission, 2 J.L. \& EcoN. 1 (1959).

185. The first broadcast radio station, KDKA of Pittsburgh, was just such an operation. See E. BARNOUW, supra note 22, at 69. 
ket is generally several millions. Additional millions in advertising revenue are needed if a station is to reinain in operation. In many markets, sufficient funding for such an undertaking may simply be unavailable.

This economic scarcity, however, cannot justify the imposition of content regulation on either the broadcast or the print medium. ${ }^{186}$ No journatist should be required to present the views of others merely because he has taken the opportunity to present his own conflicting views. This is true regardless of the economic concentration in the broadcast or print industries. While the original speaker may through financial superiority be able to disseminate his views more efficiently, those who disagree nevertheless can make their views known, be it through a competing newspaper or radio station, a handbill, or on a soapbox. That one person has and is willing to use the resources necessary for political speech does not mean that the government can require him to use those resources as a public foruin. Forcing a speaker to use his property to present political and ideological viewpoints with which he may not agree would violate the principle that the first amendinent protects not only the individual's freedom to speak but also his freedom not to speak. ${ }^{187}$ Mere economic inequality among speakers and potential speakers does not create a compelling state interest ${ }^{188}$ that overrides this protection. ${ }^{189}$

\footnotetext{
186. Professor Emerson has stated that:

An effort by government to eliminate differences based on economic disparities is an infinitely more complicated and far-reaching problem than an attempt to allocate facihties in a shortage situation. The government does have some obligation to equalize, but limiting the rights of some speakers, instead of raising disfavored speakers to a minimum level, invites disaster. A share-the-facilities program on such a large scale can only result in less communication. And it involves a degree of governmental entanglement with the system of expression that is certain to end in severe repression of communication. In this conflict between the right to know and the right to communicate, the latter must be preferred.
}

Emerson, Legal Foundations of the Right to Know, in The First Amendment and the Right to Know, 1976 WASH. U.L.Q. 1, 12-13.

187. See Wooley v. Maynard, 430 U.S. 705, 713 (1977), in which the Supreme Court held that a state may not "constitutionally require an individual to participate in the dissemination of an ideological message by displaying it on his private property in a manner and for the express purpose that it be observed and read by the public."

188. But see id. at 715-17.

189. The existence of economic scarcity in the broadcast industry, of course, cannot justify the imposition of content regulation on that industry alone, since it is present in the print mediun as well. In fact, judging from comparative statistics on radio stations and newspapers, the economic scarcity in the print medium may be more significant than that in the broadcast medium. As of December 31, 1979, there were 8,752 radio stations on the air in the United States. FCC Letter, supra note 68. By contrast, there were only 1,763 daily newspapers on February 1, 1980, EDITOR \& Publisher, 1980 EDITOR \& PUblisher InTERNATIONAL YEAR BOOK viii (1980), and while 136 cities have three or more television stations (inclusion of radio stations would raise that number substantially), only five have three or more newspapers. 1975 Hearings, supra note 88, at 17 (statement of Sen. Proxmire). 
Even if it is assumed that the concept of physical scarcity has retained its vitality since 1927, it does not by itself legitimize government interference with broadcast content. Scarcity is a technological and regulatory problem, created by a combination of natural phenomena and government intervention. ${ }^{190}$ As such, it can be used to justify regulation of the content of broadcast speech only if its proponents can show a connection between the problem-physical scarcity-and the remedy - a broadcaster duty to present balanced public issue programming - that does not exist with the print medium as well. If no such connection can be shown to exist, scarcity can be used to legitimize only solutions geared toward resolving rather than exacerbating the problems of technological limitations or government regulation of speech. The proponents of content regulation have failed to establish such an unique connection. ${ }^{191}$

\section{Impact}

A second distinguishing characteristic of the broadcast medium used in urging content regulation is that it has a greater impact on the public than the print medium. This distimction has been mentioned by the courts in several cases ${ }^{192}$ and has been advanced by some commentators as a complement ${ }^{193}$ or even alternative to the scarcity rationale, ${ }^{194} \mathrm{~m}$ justifyimg content regulation. Drawing on the amount of time that the average American spends watching television or listening to the radio, ${ }^{195}$ the preponderance of the broadcast medium as a source of news and commentary, ${ }^{196}$ and the particularly pervasive nature of the

190. See Hickey, Goodbye '70s, Hello '80s, TV GUIDE, Jan. 5, 1980, at 6, 10.

191. This failure traces back to Justice Frankfurter's majority opinion in NBC v. United States, 319 U.S. 190 (1943). In that case, the Court upheld certain FCC regulations concerning chain broadcasting that had been prounulgated under the "public interest, convenience, or necessity" standard. Justice Frankfurter justified the regulations on first ainendment grounds simply by stating that "[u]nlike other inodes of expression, radio inherently is not available to all," and that based on this "unique characteristic," broadcasting "is subject to govcrnunental regulation." Id . at 226-27. Although this analysis does justify some regulation of broadcasting, it does not establish how physical scarcity could be used as a rationale for government regulation of what broadcasters say. As stated by Professor Emerson, "[i]t did not explain why the scarcity factor eliuninated First Amendment issues, . . . [or] numerous other questions that lurked in the problem." T. EMERSON, supra note 177 , at 657 .

192. E.g., CBS v. Democratic Nat'1 Comm., 412 U.S. 94, 116 (1973); Brandywine-Main Line Radio, Inc. v. FCC, 473 F.2d 16, 79 (D.C. Cir. 1972). For a general discussion of the impact theory, see Lange, supra note 13, at 16-21.

193. E.g., Barrow, The Equal Opportunities and Fairness Doctrines in Broadcasting: Should they be Retained?, 1 Сомm/ENT 65, 74-75 (1977).

194. Barrow, supra note 88, at 494.

195. E.g., N. JoHNSON, supra note 183, at 13 (1967) ("[t]he average male viewer, between his second and sixty-fifth year, will watch television for over 3000 entire days-roughly nine full years of his life").

196. See note 165 supra. 
broadcast message, ${ }^{197}$ the proponents of the impact rationale contend that this medium has an unique and powerful effect on our lives, ${ }^{198}$ and therefore must be kept in close check lest it be abused. ${ }^{199}$ Congress probably did not consider this rationale as a justification for the public mterest standard in 1927, because it did not recognize the future impact of radio, and commercial television was then an unknown medium. ${ }^{200}$ Impact is very relevant, however, to the question of judicially imposed content regulation of broadcasting today.

While the broadcast medium, and particularly television, ${ }^{201}$ does play a significant role in shaping our perceptions of the world around $\mathrm{us}^{202}$ this impact cannot be used to justify judicial imposition of con-

197. "TV and radio offer access to immense numbers of listeners with at least part of the immediacy of person-to-person communications. This all-pervasive immediate form of press commentary gives tremendous leverage to speakers who have access to it." Bazelon, supra note 158 , at $220-21$.

198. Id. at 221. This effect can take two basic forms. "First, programming may affect behavior by reshaping attitudes, values and dispositious. . . . Second, even when radio and television leave attitudes unchanged, they may convey information to audience members and, through them, to the broader public that will be utilized in naking important political and economic decisions." Schneyer, supra note 69 , at 653 .

199. Barrow, supra note 88 , at 449 .

200. Schmidt, Pluralistic Programming and Regulation of Mass Communications Media, in COMMUNICATIONS FOR TOMMOROW, supra note 99, at 219.

201. Radio has a significant impact, although it is probably not so powerful a mediuin as television. See Barrow, supra note 88, at 490.

202. Some commentators have challenged the existence or significance of this impact. Professor Jaffe, probably the most outspoken of its critics, states that "[nI]ost of the research findings point to the conclusion that television and other mass media reinforce preexisting ideas rather than change thein." Jaffe, The Editorial Responsibility of the Broadcaster: Reflections on Faimess and Access, 85 HARV. L. REV. 768, 769 (1972) (footnote omitted). Jaffe also distimguishes between commercial advertising, which he admits has a significant impact on buying habits, and political programming, where he perceives a much higher resistance to persuasion. Id. Based on these observations, he concludes that "[b]roadcastimg lias at best an incremental and at worst a marginal effect on political consciousness." In summation, he finds "[t]he imphication that the people of this country . . . are mere unthinking automatons manipulated by the media, without interests, conflicts, or prejudices . . . quite maddening." Id. at 787.

While Professor Jaffe's sense of outrage is certainly understandable, his position is overstated. It is subject to challenge at two levels. First, his reliance on the failure of the academic literature to establish a clear relationship between the broadcast medium and our perceptions of world events is scarcely more convimcing than the reliance of some tobacco interests on the failure of science to establish a chemical link between smoking and lung cancer in denying the existence of such a link. The effects of broadcasting on our hves are subtle and complex, and are for the inost part unperceived. Bazelon, supra note 158, at 221. To require the isolation and ineasurement of such an effect before recognizing its existence is unreasonable.

Second, by focusing on the ability of broadcasting to change our views rather than its ability to shape them in the first place, Jaffe misses a major point of the impact theory. It is in affectimg the store of experiences that forms our decisionmaking processes and in influencing our perceptions of those issues on which we have not yet formulated our opmions that the broadcast inedium has its greatest impact, not in changing previously resolved opinions. See Jaffe, supra, at 770. Thus, while the impact of television and radio on our perceptions of the world is probably not plenary given the many sources front which we draw in our decisionunaking processes, it cannot be discounted as easily as Professor Jaffe suggests. 
tent regulation. ${ }^{203}$ In 1789 , the printed press was not only the most powerful means of mass communication available, it was the only means available. ${ }^{204}$ Yet it was then that the first amendment, giving nearly absolute protection to the press, was adopted imto the Constitution. This impact and the correspondingly crucial role that the press plays in our political system were precisely the reasons why the first amendment was adopted. ${ }^{205}$ If the relative impact of the various media is a valid factor at all in determining first ainendinent protections, its consideration should lead to more protection of broadcasting, not less. $^{206}$

Some abuse of this power to shape and influence perceptions and opinions is inevitable. ${ }^{207}$ But this fact cannot be used to legitimize the imposition of government content regulation, for the first amendment strikes its own balance between the benefits and the dangers of a free press, and favors the former. ${ }^{208}$ Some abuse inust be tolerated if the press is to remaim free. ${ }^{209}$

\section{Public Ownership}

A final rationale used to justify content regulation of the broadcast medium is the public ownership theory. ${ }^{210}$ This rationale rests on the notion, adopted by the Supreme Court in National Broadcasting Co. $v$. United States, that the airwaves are pubhic property, ${ }^{211}$ and therefore can be regulated by the government for the public good. Under this

203. For a criticism of the impact rationale that takes a different approach, see Bollinger, supra note 158 , at $13,16$.

204. Brandywine-Main Lime Radio, Inc. v. FCC, 473 F.2d at 79.

205. As former FCC Commissioner Nicholas Johnson put it, "[t]he press must forever be beyond the power of government so that government will never be beyond the power of the press." N. JoHnson, supra note 183, at 102.

206. See Brandywine-Main Line Radio, Inc. v. FCC, 473 F.2d at 79; Comment, supra note 154, at 766-67. This is true even where ownership of broadcast outlets is concentrated. See generally notes 251-64 and accompanying text infra. Professor Emerson, for example, has stated that government intervention in the system of communication on the basis of economic concentration would be an invitation to disaster, ultimately resulting in severe governinent repression of speech. See note 186 supra.

207. As Madison said, "[s]ome degree of abuse is inseparable froin the proper use of every thing; and in no instance is this more true than in that of the press." 4 Elliot's Debates ON THE Federal Constitution 571 (1876), quoted in New York Times Co. v. Sullivan, 376 U.S. 254, 271 (1964).

208. See Miami Herald Publishing Co. v. Toruillo, 418 U.S. 241, 260 (1974) (White, J., concurring).

209. Rosenbloom v. Metrounedia, Inc., 403 U.S. 29, 51-52 (1971).

210. This theory has also been called the public domain or privilege theory. See Comment, supra note 154 , at 767.

211. "[B]oth radio and television broadcasting utilize a natural resource-the electromagnetic spectrum-that is part of the public domain. And, although broadcasters are granted the temporary use of this valuable resource for terminable three-year periods, 'ownership' and ultimate control remain vested in the people of the United States." 418 U.S. at 173-74 (footnote omitted). 
theory the government, as public trustee, ${ }^{212}$ lias decided that the public interest would be best served through a system of private broadcasters, licensed to operate for limited periods of time. ${ }^{213}$ Thus, the use of the airwaves by the private broadcaster is a privilege, not a right, ${ }^{214}$ and therefore can be made subject to reasonable government regulation. ${ }^{215}$

Commentators have argued that because the broadcase spectrum is intangible it cannot be owned. ${ }^{216}$ Even if the broadcast spectrum can be owned, that fact is not in itself a legitimate basis for content regulation. The public owns municipal streets and parks, but that does not inean that the government can therefore regulate tlie speech of those using them. ${ }^{217}$ The courts have consistently rejected sucli assertions as contrary to the first amendment right of free speech. ${ }^{218}$ Similarly, public ownership of the ineans of disseminatimg written speech-such as the postal service-does not justify government control of its content. ${ }^{219}$ The relationship between public ownership of the airwaves and the imposition of content-based regulation on broadcasters sliould be no different.

Because no distinction relevant to the question of content regulation exists between the print and broadcast media, the two media should be treated equally in discussing the constitutionality of sucli regulation. Any duty that legitimately can be imposed on one medium can also be imposed on the other, and conversely, any duty that cannot be imposed on one inediun also cannot be imposed on the otler. This conclusion represents a significant clrange from the traditional imterpretation, ${ }^{220}$ as the broadcast mediun generally has received less judicial protection than the print mediun. ${ }^{221}$

212. NBC v. FCC, 516 F.2d 1180, 1192 (D.C. Cir. 1975) (separate opinion of Tamm, J.) (vacating as moot 516 F.2d 1101 (D.C. Cir. 1974)), cert. denied, 424 U.S. 910 (1976).

213. Other options included government operation of all broadcast facilities or the creation of a public corporation for broadcasting.

214. Television Corp. v. FCC, 294 F.2d 730, 733-34 (D.C. Cir. 1961).

215. Mayflower Broadcasting Corp., 8 F.C.C. 333, 340 (1940).

216. Robinson, supra note 53, at 152-53. "To say that the airways or spectrum can be owned by anyone is simply to indulge in fantasy. Snrely no one seriously supposes that the airways are a thing of nature which can be possessed, occupied, or used in any normal sense of the word." Id. at 152. Even if the theory were put in terms of ownership of the right to use the airways, the theory could not justify government regulation, since it could be too easily extended to justify regulation of other types of speech, even reaching "backyard gossip." Id. at 152-53.

217. T. EMERSON, supra note 177 , at 660 .

218. See, e.g., Kunz v. New York, 340 U.S. 290, 293-94 (1951).

219. See, e.g., Hannegan v. Esquire, Inc., 327 U.S. 146 (1946).

220. This "traditional interpretation" is based on the statement in Josepl Burstyn, Inc. v. Wilson, 343 U.S. 495, 503 (1952) (motion pictures), that differences between inedia justify divergent first amendment approaches, since "[e]ach method [of expression] tends to present its own peculiar problems."

221. Compare Miami Herald Publishing Co. v. Tornillo, 418 U.S. 241 (1974), with Red Lion Broadcasting Co. v. FCC, 395 U.S. 367 (1969). 


\section{B. Application of the Right to Hear in the Broadcast Context}

In atteinpting to impose a constitutional duty to present a full and fair discussion of public issues on the broadcast press, the plaintiff would rely on the first amendment "right to hear." Defined as the reciprocal of the right to free speech, ${ }^{222}$ this right has been applied by the courts only in other contexts. ${ }^{223}$ Recently, however, the Court intimated that it might cover the listener's right to hear a range of views. ${ }^{224}$ The notion also has some prior basis in the broadcast context, most notably in the FCC's statement that "[i]t is the right of the public to be informed, rather than any right on the part of the Government, any broadcast licensee or any individual meinber of the public to broadcast his own particular views on any matter, which is the foundation stone of the American systein of broadcasting."225 It is this right to hear, the plaintiff would argue, that gives rise to an affirmative duty on the part of the broadcaster to provide broad and adequate information on a variety of subjects. 226

This approach to the right to hear, however, cannot be squared with the first ainendment in theory or in practice. The court instead should follow the Supreme Court's reasoning in Miami Herald Publishing Co. v. Tornillo. 227

At issue in Tornillo was a Florida statute closely resembling the personal attack doctrime upheld in Red Lion. If a newspaper attacked the character or record of any candidate for public office, the statute required the newspaper to print the candidate's reply, so long as the response was no longer than the original editorial. ${ }^{228}$ The Court unani-

222. Note, The Listener's Right to Hear in Broadcasting, 22 STAN. L. REv. 863, 867 (1970). The commentator draws a distinction between this right and the right of access to the means of free speech, which he considers an extension of the right to free speech itself. Id. The right of access, however, if motivated by a desire to give air time for the exposition of the various views on important public issues, can be legitimately considered a component of the right to hear, simce it represents a possible means through which this right can be protected.

223. See, e.g., Griswold v. Connecticut, 381 U.S. 479, 482 (1965) (right to receive information on contraception from doctor); Lamont v. Postunaster General, 381 U.S. 301, 308 (1965) (right to receive communist publications). For a more general discussion of the right to receive information, see Kleindienst v. Mandel, 408 U.S. 753, 762-65 (1972).

224. "lt is the right of the public to receive suitable access to social, political, esthetic, moral, and other ideas and experiences which is crucial here." Red Lion Broadcasting Co. v. FCC, 395 U.S. 367, 390 (1969) (dictum).

225. Editorializing by Broadcast Licensees, 13 F.C.C. 1246, 1249 (1949). This passage is strikingly similar to the statement in Red Lion that "[i]t is the right of the viewers and listeners, not the right of the broadcasters, which is paramount." 395 U.S. at 390. An even earlier expression of this sentiment can be found in NBC v. United States, 47 F. Supp. 940 (S.D.N.Y. 1942) (thrce-judge court), aff d, 319 U.S. 190 (1943), in which Judge Learned Hand said that "the First Amendment ... protects . . the interests, first, of the 'listeners' . . ."

226. See Note, supra note 222 , at $867-68$.

227. 418 U.S. 241 (1974).

228. Id. at 244 . 
mously held the statute invahd on its face as a violation of the first amendment. This conclusion was based on two rationales. First, the Court held that such a law inevitably would produce a "chilling effect" on newspaper coverage of candidacies and elections. "Faced with the penalties that would accrue to any newspaper that published news or commentary arguably within the reach of the right-of-access statute, editors might well conclude that the safe course is to avoid controversy," 229 a result clearly inconsistent with the first amendment. Second, the Court objected to the government intrusion into the editorial processes of the newspapers that the statute would produce, and concluded that "[i]t has yet to be demonstrated how governmental regulation of this crucial process can be exercised consistent[ly] with First Amendment guarantees of a free press as they have evolved to this time." 230

Although not a broadcasting case, Tornillo inarked a significant change im the Court's approach to the first amendment. It was the first case to suggest that the guarantee of a free press includes a guarantee of press autonomy, ${ }^{231}$ a precedent that readily can be extended to broadcasting. Tornillo also advanced a proposition that the Court was unwilling to accept in Red Lion ${ }^{232}$ - that government intrusion imto the editorial process, through content regulation such as was found in the Florida statute and also may be found in the fairness doctrine, inevitably inhibits the coverage of the topics so regulated. This proposition, combimed with the prior conclusion that the print and broadcast media cannot be distinguished with regard to content regulation, ${ }^{233}$ significantly weakens Red Lion's precedential value to the hypothetical plaintiff.

\section{Misapplication of the Right to Hear}

The concept of content regulation of the mass inedia rests primarily on the "right to hear." 234 Under this analysis, the main purpose of freedom of speech is to produce an informed citizenry that is thus better able to determine public pohicy. ${ }^{235}$ As recently stated by the FCC:

229. Id. at 257.

230. Id. at 258 .

231. B. Schmidt, Freedom of the Press vs. Public Access 237 (1976).

232. 395 U.S. at 392-93. Note, however, that the Court in Red Lion indicated that it might reconsider its holding if a chilling effect were found. Id. at 393.

233. See notes 157-221 and accompanying text supra.

234. See, e.g., Note, supra note 222.

235. E.g., Barrow, supra note 88, at 495 . This policy has been described in various ways. E.g., Red Lion Broadcasting Co. v. FCC, 395 U.S. 367, 390 (1969) (goal is to achieve a "inarketplace of ideas"); New York Times Co. v. Sullivan, 376 U.S. 254, 269 (1969) (goal is to achieve an "unfettered interchange of ideas"); Green v. FCC, 447 F.2d 323, 329 (D.C. Cir. 1971) ("the American public must not be left uninformed") (emphasis in the original). 
"[T]he purpose of the First Amendment is not simply to protect the speech of particular mdividuals, but rather to preserve and promote the informed public opinion which is necessary for the contmued vitality of our democratic society and institutions."236

Historically, the information function could be left to the marketplace. Newspapers and other printed material were the only means by which infornation was disseminated, and entry into this market was relatively easy. Therefore, most if not all viewpoints would be presented and advocated by the many sources of inforination. In this situation, in which the multiplicity of speakers ${ }^{237}$ could be relied on to inform the public adequately, the purpose of the first amendment was to protect them from government interference.

Given the concentration in the mass media today, ${ }^{238}$ however, advocates of content regulation clain that some affirmative obligation on the part of the press to provide information and viewpoints on important public issues is necessary to maintain an inforined citizenry. This obligation, they claim, is particularly crucial with regard to broadcasting, where entry is limited $\mathrm{d}^{239}$ and where the three major networks control much of what is broadcast. ${ }^{240}$ Thus, the court inust imtervene between the broadcast speaker and listener, ${ }^{241}$ requiring the former to present balanced public issue programming for the benefit of the latter. The court, the advocates of the right to hear would conclude, would thereby protect the constitutional right of the public to hear the "range of ideas and experiences"242 necessary for democratic self-determination.

A constitutional right to hear clearly exists, for without it freedom of speech would be worthless. Only if people are allowed to listen, see, or read can the guarantee of free speecl have any meaning. The right to hear, however, does not entail content regulation. Such an interpretation of the first amendment cannot withstand constitutional analysis for several reasons.

First, it inisconceives the nature of our democratic system. While an informed citizenry is certainly a laudable goal, it is not as essential to the determination of public policy as its proponents assume. The American democratic system is representative, not direct; the role of

236. Fairness Report, supra note 60 , at 5 .

237. See Abrams v. United States, 250 U.S. 616, 630 (1919) (Holmes, J., dissenting).

238. See notes 184-85 and accoinpanying text supra.

239. This limitation has traditionally been defined in physical terms, since the broadcast spectrum is limited in size. See notes 166-71 and accompanying text supra.

240. See note 4 supra.

241. Comment, Media and the First Amendment in a Free Society, 60 GEo. L.J. 867, 1039 (1972).

242. Note, supra note 222 , at $867-68$. 
the individual citizen is therefore indirect. ${ }^{243}$ "Since the Constitution does not establish a direct dennocracy, the inference of a right to [hear] cannot find its constitutional source in the view of popular sovereignty which contemplates direct citizen participation in the making and administration of laws." 244

Second, even if the Constitution did contemplate direct popular sovereignty, the right to hear cannot be justifiably extended by judicial precedent or by sound constitutional interpretation to the issue of content regulation. Every case in which the Supreme Court has applied the right to hear doctrine $e^{245}$ has involved a direct government restraint on speech. In each instance, the government had prevented communication between a willing speaker and a willing listener. The only question before the Court was whether the government niterest allegedly furthered by preventimg the communication was so conpelling as to override the first amendment interests of the public in permitting it. In applying the right to hear, the Court abridged no one's first ainendment rights; the government asserted none, and the protection of communication between the speaker and the listener violated no one else's rights. ${ }^{246}$

Likewise, sound constitutional interpretation of the right to hear does not mandate or even justify content regulation. Proponents of such regulation would argue that application of the right to hear in the broadcast context entails the right to receive a broad range of ideas and viewpoints. This interpretation of the first amendment, lowever, posits not only a right to hear but also a duty to speak, ${ }^{247}$ because if the public is to receive the range of viewpoints and ideas envisioned by content regulation, soineone inust present them. This would stand the first amendment on its head, as it would permit soine sense of the "public good" to override the right of the individual to speak or not to speak without government interference. ${ }^{248}$

243. BeVier, An Informed Public, An Informing Press: The Search for a Constitutional Principle, 68 CALIF. L. REv. 482, 505 (1980). This, of course, is not meant to imply that an informed public is not an important goal. Public opinion often plays a leading role in determining national policies. The importance of this goal, however, should not be overstated, and cannot be used to relegate the constitutional guarantee of freedom of the press, which is specifically provided for in the Constitution, to a secondary status.

244. Id. at 506. Although stated in a discussion of the press' right to government-held information, this statement is fully applicable here.

245. E.g., Kleindienst v. Mandel, 408 U.S. 753, 762-65 (1972); Lamont v. Postmaster Gen., 381 U.S. 301 (1965); Martin v. City of Struthers, 319 U.S. 141, 143 (1943). The Supreme Court has never expressly adopted the right to hear im a broadcast context.

246. See Note, Constitutional Ramifications of a Repeal of the Fairness Doctrine, 64 GEO. L.J. 1293, 1312 (1976).

247. 2d Fairness Report, supra note 69, at 706 (citing Hohfeld, Some Fundamental Legal Conceptions As Applied to Judicial Reasoning, 23 Y ALE L.J. 16, 31-32 (1913)).

248. 2d Fairness Report, supra note 69, at 707. 
Third, such an application of the right to hear would infringe on the broadcaster's right to speak. The broadcast day is clearly limited. ${ }^{249}$ If content regulation were imposed, the broadcaster would be required to present programming that he would not in his editorial discretion otherwise present. ${ }^{250}$ He therefore would be denied, for a portion of the broadcast day, the right to speak so that those with other views can have access to a medium not norinally available to them. Substitution by the government of one speaker for another is directly contrary to the first amendment. As the Supreme Court stated in Buckley v. Valeo, "the concept that the government may restrict the speech of some elements of our society in order to enhance the relative voice of others is wholly foreign to the First Amendment."251

\section{Protection of a Free Press}

The goal of the fairness doctrine was to encourage the broadcaster to devote substantial programming to the full and fair discussion of important public issucs. Embodymg a basic tenet of responsible journalism, this goal can hardly be faulted. It also cannot be legislatively or judicially required.

The public is best served by responsible broadcasters sensitive to the needs and interests of the listening public, unfettered by government editorial interference. ${ }^{252}$ In the ideal world, content control would be unnecessary. The plaimtiff here, however, would argue that modern broadcasting does not satisfy this ideal. The major networks control most television programming. ${ }^{253}$ The ability to inform through this most powerful medium ${ }^{254}$ thus rests with the very few. They make their programming decisions at the national or, at best, at the regional level. To a large extent they are thus isolated from the needs and desires of the local commumities they serve, a problem that is not cured

249. Courts have recognized that the capability of newspapers to disseminate information is also limited, although not as starkly so. In Miami Herald Publishing Co. v. Tornillo, the Court stated that while newspapers have no inherent limitation in size, they are restrained by such considerations as circulation, amount of advertising, the availability of newsprint, and the nced to avoid bulky, unwieldy papers. 418 U.S. at 256-57 \& n.22 (quoting Bagdikian, Fat Newspapers and Slim Coverage, Colum. Journalism Rev., Sept./Oct. 1973, at 19.

250. For a parallel discussion of government interference into the editorial processes of newspaper publishers, see Miami Herald Publishing Co. v. Tornillo, 418 U.S. at 256.58.

251. 424 U.S. 1, $48-49$ (1976). The Court excepted broadcast speeeh froin this protective holding. Id. at $49 \mathrm{n.55}$. This exception, however, is based on the scarcity rationale, a distinction that this Comment argues is invalid for first amendinent purposes. See notes 166-91 and accoinpanying text supra.

252. Brenner, Government Regulation of Radio Program Format Changes, 127 U. PA. L. Rev. 56, 83-84 (1978).

253. See Note, A Regulatory Approach to Diversifying Commercial Television Entertainment, 89 Y ALE L.J. 694, 696-97 (1980).

254. See notes 195-202 and accompanying text supra. 
by the more localized nature of the individual licensees. Moreover, the broadcaster makes its programming decisions often on the basis of personal or organizational interests ${ }^{255}$ or in order to please advertisers, ${ }^{256}$ rather than on the basis of a perceived social or public interest. This has resulted in a high level of hoinogeneity and a low level of prograin quality among the various sources of broadcast information. ${ }^{257}$

Thus, the plaintiff would assert that the broadcaster is failing in his role as an unbiased informer. Public issue programming, never a strong moneymaker, ${ }^{258}$ is too often shelved in favor of low quality entertainment programming. ${ }^{259}$ When the broadcaster does show issueoriented programming, it often fails to deal adequately with the problems presented. ${ }^{260}$

The public would probably be better off if the broadcaster's practices came closer to the ideal. This conclusion, however, does not legitimize government regulation of broadcast content. While a free flow of information on public issues may be a first amendment "value," protection of the press from government interference is the first amendment itself. $^{261}$

Under the first amendment, neither court nor legislature is permitted to interfere in the news gathering and disseminating functions of the press. This ultimately may not produce a full and fair exposition of many major political issues; coverage of issues may be slanted or inadequate. This risk does not, however, permit the government to balance the public mterest in receiving information against the private interest of the broadcaster in retaining editorial discretion, for the framers did the relevant balancing, resolving that balance in favor of the broadcaster. ${ }^{262}$ Confronted with the possibility that the press might abuse its power or fail to use it for the greatest public good, but recognizing that

255. OPTIONS PAPERS, supra note 4, at 66-67; 1975 Hearings, supra note 88, at 52 (statement of Richard E. Wiley, then Chairman of the FCC).

256. N. Johnson, supra note 183, at 82; Barrow, supra note 88, at 487, 492, 545-46.

257. See Note, supra note 253, passim.

258. Public issue programming generally appeals only to a portion of the viewing or listening audience, and thus is rarely profit-maximizing. See generally Schneyer, supra note 69, at 652-53.

259. See, e.g., N. MnNow, EQUal TIMe 52 (1964) (characterizing television programming as "a vast wasteland").

260. See Comment, We Pick 'Em, You Watch 'Em: First Amendment Rights of Television Viewers, 43 S. CAL. L. Rev. 826, passim (1970).

261. As eloquently stated by Justice Stewart, we must not "lose sight of the First Amendment itself, and march forth in blind pursuit of its 'values.' " CBS v. Democratic Nat'l Comm., 412 U.S. 94, 145 (1973) (Stewart, J., concurring).

262. In the words of Justice White, "the press is not always accurate, or even responsible, and may not present full and fair debate on important public issues. But the balance struck by the First Amendment with respect to the press is that society must take the risk that occasionally debate on vital matters will not be comprehensive and that all viewpoimts may not be expressed." Miami Herald Publishing Co. v. Tornillo, 418 U.S. at 260 (White, J., concurring). 
to give any portion of that power to the government would be to invite state repression of speech, ${ }^{263}$ the drafters of the first amendinent, and the legislatures that ratified it, chose to risk the former in order to avoid the latter.

Advocacy of any issue is inherently one-sided. ${ }^{264}$ Yet this advocacy represents a major role of the press. The press has long acted as a check on the government, following its actions and alerting the public of its excesses. If this valuable role of the press is to continue, freedom of that press must remain inviolate. "[T]he press must forever be beyond the power of government so that government will never be beyond the power of the press. Government can at no time dictate to the press because the press must, soinetimes, lead the people."265

The imposition of content regulation inevitably would reduce the amount of public advocacy engaged in by broadcasters, jeopardizing this leadership role of the press. If required to achieve some balance in their presentation, few advocates would find it worth the cost. ${ }^{266} \mathrm{~A}$ valuable tool of democracy, the marketplace of ideas where coinpetition can decide their value ${ }^{267}$ and where government excesses can be checked, thus to some extent would be lost. Instead, the first annendment must be interpreted so as to maximize the goal of public debate. Freedom of broadcasters to express their views without government interference is the best way to achieve that goal.

\section{The Duty to Present Balanced Coverage of Public Issues}

Even if the court determines that there is a constitutional right to receive adequate access to information and viewpoints on important public issues, the remedy the hypothetical plaintiff would request is both unnecessary and improper. It is unnecessary because the right to hear is adequately satisfied through the marketplace. It is improper because it would produce a chilling effect on broadcast coverage of such issues. This effect would be counterproductive and not justifiable on the basis of a coinpelling state interest.

\section{Market Provision of Ideas and Viewpoints}

While the plaintiff would assert that broadcasters inust be required to present balanced public issue programming if the public interest is to

263. The fairness doctrine was abused by several Administrations, and such abuse could be expected again if content regulation were reintroduced. For a discussion of such abuse see the dialogue between Sen. Goldwater, the target of much Johnson Administration abuse, and Sen. Proxmire, 1975 Hearings, supra note 88, at 12-13; Bazelon, supra note 158, at 236.

264. Robinson, supra note 53 , at 140 .

265. N. JoHNSON, supra note 183 , at 102.

266. Robinson, supra note 53 , at 140.

267. See Abrams v. United States, 250 U.S. 616, 630 (1919) (Holmes, J., dissenting). 
be adequately served, the realities of modern broadcasting do not support that allegation. Even admitting that the public interest demands that the public have access to a wide variety of ideas and opinions on important public issues, that demand is served adequately without such a requirement.

This conclusion is based on two factors. The first is the diversity and performance of broadcasters themselves. The number of broadcast voices available to the average listener is large and growing, particularly since the emergence of cable and other new commuincations technologies. ${ }^{268}$ Given the diversity of viewpoints those "voices" generally espouse, it is likely that opposing points of view on inost public issues would be aired. ${ }^{269}$ The broadcasters generally have exceeded the requirements of the fairness doctrine. ${ }^{270}$ Due to the absence of the "chilling effect" produced by content regulation, that standard of performance is unlikely to decline. ${ }^{271}$

The second factor is the ovcrall marketplace for ideas. ${ }^{272}$ Broadcasting, and the individual broadcasting station, cannot be isolated when pubhic access to ideas and viewpoints is discussed. Other ineans of pohtical communication, mcludimg newspapers, inagazines, and books as well as the inore traditional leaflet, podium, and soapbox, must be considered as well. When all these sources of inforination and opinions are considered, the possibility that a particular viewpoint will not be available to the public is slight. ${ }^{273}$

\section{Chilling Effect}

Broadcasters ${ }^{274}$ and commentators ${ }^{275}$ have long contended that the existence of content regulation inhibits the coverage of controversial

268. Many of those involved with the broadcasting industry see cable television as providing a revolution in pubhic issue programming. See, e.g., N. JoHNSON, supra note 183, at 152; Hickey, supra note 190 , at 13 . One observer envisions cable as a possible "video magazine," devoting programming to a variety of special interest issues. Id. (quoting $\mathrm{H}$. Geller).

269. See 1975 Hearings, supra note 88, at 17 (statement of Sen. Proxmire).

270. 1979 Hearings, supra note 89, at 2629 (statement of Sen. Proxmire) (quoting C. Ferris, Chairman of the FCC); id. at 1982 (statement of Sen. Goldwater).

271. See notes 274-303 and accompanying text infra.

272. 1979 Hearings, supra note 89 , at 2140 (statement of G. Jankowski).

273. 1975 Hearings, supra note 88, at 23 (statement of Sen. Proxmire); Blake, Red Lion Broadcasting Co. v. FCC: Fairness and the Emperor's New Clothes, 23 FED. COM. B.J. 75 (1969); Robinson, supra note 53, at 142-43. "[W] have to recognize that with all the radio voices that exist, with all the television voices, with all the newspapers and inagazines that we have, Americans are not left wanting for information about the world in which they liv[e]." 1979 Hearings, supra note 89, at 2161 (statement of G. Jankowski).

274. E.g., 1975 Hearings, supra note 88, at 77 (statement of J. Goodman); 1979 Hearings, supra note 89, at 2486 (statement of E. Bohi).

275. E.g., Schmidt, supra note 99, at 202; Schneyer, supra note 69, at 670-71; Simmons, supra note 173 , at $45-48$. 
issues on radio and television. Content regulation, they argue, is in effect counterproductive: designed to increase programming on such issues, it actually decreases it. ${ }^{276}$ The probability of such an effect would be likely to form a key counterarguinent in plaintiff's action.

According to those who assert its existence, the chilling effect has two coinponents. The first is the expense involved in dealing with an accusation of unbalanced coverage. When a prograin dealing with a controversial issue is presented, deinands for reply time are inevitable. ${ }^{277}$ Normally, these are refused; as the next step, the deinanding parties file coinplaints with the FCC. ${ }^{278}$ While the FCC disinisses inost complaints without referring thein to the broadcaster for comment, a significant number do reach the broadcaster. ${ }^{279}$

It is at this point that the expense begins. The broadcaster inust devote the time of key personnel to the investigation of the coinplaint, prepare correspondence with the FCC, and consult attorneys both 10cally and in Washington. ${ }^{280}$ This activity can cost a small broadcaster $\$ 20,000$ or more, and more than $\$ 100,000$ if a major network becoines involved ${ }^{281}$ - all to determine, in most instances, only that the broadcaster had provided an adequately balanced coverage of the relevant issues.

If the FCC determines that this balance has not been adequate, the cost is even higher. The broadcaster inust then devote valuable air time, often at no charge to the speaker, ${ }^{282}$ to the presentation of an opposing viewpoint. This, of course, reduces the broadcast time available for programming the broadcaster deeined inore valuable ${ }^{283}$ or for advertising.

The second coinponent of the chilling effect is the possibility that the FCC will revoke or refuse to renew the broadcaster's hicense because it failed to present the desired balance. ${ }^{284}$ Thus, every time a

276. Chief Judge Bazelon suggested this probability in his classic dissent in Brandywine-Main Line Radio, Inc. v. FCC, 473 F.2d 16, 79-80 (D.C. Cir. 1972) (Bazelon, C.J., dissenting), urging that the FCC and the courts reexamine the rationale behind the original imposition of the fairness doctrine.

277. Powe, "Or of the [Broadcast] Press," 55 Tex. L. REv. 39, 54 (1976).

278. Schneyer, supra note 69 , at 671 .

279. See note 68 supra.

280. W. Francois, Mass Media Law and Regulation 339 (1975) (quoting NBC President Julian Goodman); Schmidt, supra note 99, at 202-05. For a good description of the chilling effect, see Simmons, supra note 173 , at $46-47$.

281. Simmons, supra note 173 , at $45-46$. As the price of attorneys' services continues to rise, and as the issues presented become inore complex, the cost can also be expected to rise.

282. See Cullman Broadcasting Co., 40 F.C.C. 576 (1963). See generally notes 60-63 and accompanying text supra.

283. If this were not trne, the broadcaster would have aired the opposing viewpoint voluntarily.

284. The FCC can presently take such an action under the faimess doctrine. 47 U.S.C. 
program elicits a request for the presentation of alternative viewpoints, the broadcaster must consider the effect of its refusal on license renewal. The risk that the FCC will impose such a sanction is actually very small, ${ }^{285}$ the possibility, however, is always present and therefore cannot be ignored.

Faced with these possibilities, it is not surprising that the broadcaster may reduce the station's coverage of controversial issues, especially if it has gone through the complaint process before. In that way the broadcaster minimizes the probability that it must undergo sucls an ordeal. ${ }^{286}$

Because documentaries and other issue-oriented programming are traditionally the least lucrative broadcast formats, ${ }^{287}$ this chilling effect assumes an even greater significance. It is mucli less painful to cut back on low profit programming than it is to cut a moneyinaker. ${ }^{288}$ The result is a "fastidiously balanced coverage of very few controversial issues"289 rather than the "uninhibited, robust, and wide-open"290 debate envisioned by the proponents of content regulation.

To counter this defense, the plaintiff has several possible arguments. The first is that no chilling effect exists, or that if one does exist, it is insignificant. ${ }^{291}$ This contention relies largely on the lack of any verifiable evidence showing such an effect. ${ }^{292}$ While certainly accurate empirically, this argument, like that concerning the effect of broadcasting on our perceptions of the world, ${ }^{293}$ is based on an unrealistic standard of scientific proof. Any attempt to determine the aniount of public issue programming that would have been presented in the absence of content regulation would be dooned to failure. The actual determinants of a broadcaster's programming decisions are almost impossible to reconstruct. Moreover, no reliable comparative evidence

§ 312(a) (1976 \& Supp. II 1978). That sanction would probably also be available under the plaintiffs proposed remedy.

285. See note 68 supra.

286. In the words of one broadcaster:

It stands to reason that no broadcast manager in his right mind is going to put his station's license on the line by knowingly incurring the displeasure of those in high places who lave the power to take the license away. He's not going to go out of his way to incur the regulatory hassle and legal expense which controversy often brings.

1979 Hearings, supra note 89, at 2486 (stateinent of E. Bohi).

287. Bazelon, supra note 158 , at 230.

288. This effect is likely to be felt most seriously by the individual licensee rather than the large network, since the licensee generally has less capital and nanpower with which to deal with a complaint.

289. Schneyer, supra note 69 , at 671 .

290. New York Times Co. v. Sullivan, 376 U.S. 254, 270 (1964).

291. See, e.g., Fairness Report, supra note 60, at 7; 1977 Hearings, supra note 5, at 58-59 (statement of H. Geller); 1975 Hearings, supra note 88, at 58 (stateinent of Sen. Huddleston).

292. See, e.g., Fairness Report, supra note 60 , at 8.

293. See note 202 supra. 
exists, as broadcasters have been subject to content regulation throughout the modern era of broadcast journalism. ${ }^{294}$ Thus, the only available data are the perceptions of individual broadcasters, ${ }^{295}$ and the few specific mstances in whicl a broadcaster is known to have considered content regulation when making programming decisions. ${ }^{296}$

As evidence of his assertions, the plaintiff might cite the statements of some broadcasters that they liave not been inhibited by the fairness doctrine, ${ }^{297}$ and the results of a poll reported by Professor Barrow ${ }^{298}$ indicatimg that only nine percent of the broadcasters polled perceived such a chilling effect. This line of arguinent in support of content regulation, however, is unpersuasive and inappropriate. Even if only nine percent of all broadcasters are inhibited by content regulation, they nevertheless represent a significant portion of the broadcast community. More importantly, reliance on statistical evidence is always questionable $\mathrm{m}$ cases involving freedom of speech. In no other area has the Supreme Court even considered sucl evidence. The mere possibility of a chilling effect was all the Court needed in order to assume its existence for constitutional purposes. ${ }^{299}$ A constitutional guarantee cannot be infringed justifiably on the assertion that few feel any ill effects.

A second answer to the chilling effect defense miglit be that content regulation was designed to enhance coverage of controversial issues, not to inhibit it. The broadcaster's decision not to present such coverage, because of content regulation, would be inconsistent with its purpose and therefore would not be a valid criticism of the regulation. 300 This arguinent, however, confuses purpose with effect.

294. The time between the repeal of the fairness doctrine and the lawsuit posited here would provide some basis for a comparative analysis, but the results of such an analysis can only be hypothesized at this point. Moreover, that result might be skewed by a conscious decision on the part of broadcasters to present a significant amount of public issue programming in the period immediately following the repeal in an attempt to forestall any possibility that Congress might reenact the fairness doctrine.

295. See, e.g., 1979 Hearings, supra note 89, at 2486 (statement of E. Bohi); 1977 Hearings, supra note 5, at 117 (statement of J. Goodman).

296. For an exaunple of such an instance, see W. FraNCOIS, supra note 280, at 340.

297. 1975 Hearings, supra note 88, at 58 (statement of Sen. Proxmire); id. at 77 (statement of E. Rule).

298. Barrow, supra note 193, at 92.

299. See, e.g., Miami Herald Publishing Co. v. Tornillo, 418 U.S. 241 (1974). The absence of hard evidence of a chilling effect did not prevent the Tornillo Court from striking down the statute involved in that case. Logically, the effect existed, even though the statute had been enforced only twice in 61 years. 418 U.S. at 247. The Court needed no statistical evidence of an imhibition. Its potential was sufficient. See id. at 257 . $C f$. Shelton v. Tucker, 364 U.S. 479 (1960) (statute requiring teachers to disclose organizations to which they belong is invalid because of potential impairment of freedoin of association).

300. See, e.g., Cox, The FCC and the Future of Broadcast Journalism, in ALFRED I. DUPONTColumbia University, SURVEy of BroadCAST Journal.1SM: 1969-1970 112, $115-19$ (1970); Fairness Report, supra note 60, at 7. 
Whether the broadcaster's perception of a chilling effect is "correct" or not is irrelevant to the question of whether it exists. ${ }^{301}$ Content regulation may have been intended to produce a diverse and informative discussion of public issues, but this fact cannot be used to justify its contimuation after it has been found to be counterproductive.

A third possible argument, infrequently advanced, is that any chilling effect would be irrational, because the FCC is so lax in its enforcement of content regulation that the actual magnitude of the regulation's impact is insignificant. ${ }^{302}$ This line of argument fails for three reasons. First, although the rules are not stringently enforced now, there is no assurance that they will not be so enforced in the future, particularly since ultimate enforcement responsibility would be in the hands of the court, not the FCC. Second, given the extremely high cost involved in justifying one's programming decisions before the FCC, even a sinall possibility of such enforcement proceedings inay be sufficient to produce an inhibiting effect. Finally, laxity in enforcement can hardly be used to justify content regulation. If it is not enforced, a serious question exists whether it should be imposed at all. ${ }^{303}$ Thus, the court should recognize a significant chilling effect as a probable result of content regulation.

\section{Compelling State Interest}

Even if the plaintiff cannot successfully counter the chilling effect defense, he may yet succeed in his action if he can prove that content regulation, though possibly infringimg the right to freedom of speech, furthers some compelling state interest. ${ }^{304}$ This tactic has two eleinents: First, the action must further the compelling interest asserted; and second, it must do so by the ineans least restrictive of the broadcaster's first amendment rights. ${ }^{305}$

The plaintiff would argue that content regulation serves the coinpelling state interest in assurmg the provision of sufficient information on controversial public issues to the public so that it may make intelligent decisions on public policy. ${ }^{306}$ However, content regulation does not adequately further this interest. ${ }^{307}$ There is no assurance that a per-

301. See Schmidt, supra note 99, at 202.

302. Barrow, supra note 88, at 487-88; Cox, supra note 302, at 119.

303. Simmons, supra note 173 , at 48 .

304. "[O]nly a compelling state interest in the regulation of a subject within [the state's] power to regulate can justify hmiting First Amendment freedoms." NAACP v. Button, 371 U.S. at 438.

305. Shelton v. Tucker, 364 U.S. 479, 487-88 (1960).

306. For a discussion of the first amendment basis of this interest, see notes 243-44 and accompanying text infra. For the purposes of this discussion, its validity is assumed.

307. There must, of course, be a correlation between the state interest asserted and the govermment action in question if that action is to be maintained. See, e.g., Shelton v. Tucker, 364 U.S. at 485 . A correlation, however, will not justify the action unless the interest is sufficiently 
son who hears one viewpoint on an issue also will hear the opposing viewpoint. $^{308}$ Thus, unless the regulation requires the broadcaster to present both viewpoints on the same prograin-a notion that has repeatedly been rejected by the courts as an unconstitutional infringement on the broadcaster's editorial discretion ${ }^{309}$-content regulation does hittle more than provide for the presentation of an additional viewpoint, without assuring any balance for the listener.

Moreover, by focusing solely on the balance of viewpoints presented by an individual broadcast station, content regulation ignores the fact that the balance desired generally will be provided by other stations and otler media. A single broadcast station is not a communications monopoly; rather, it shares this market not only with other broadcasters, but also with the print and other media. Since this marketplace generally provides the public with sufficient access to a broad range of ideas and viewpoints, ${ }^{310}$ content regulation is not necessary to fulfill that purpose. Finally, content regulation is probably counterproductive, inhibiting rather than enhancing public issue programming. ${ }^{311}$ Thus, the correlation required between the relief requested and the interest asserted is lacking, and therefore that remedy must be denied.

Even if the plaintiff could establish an adequate relationship between content regulation and the goal of an inforined public, his action should nevertheless fail because less restrictive means are available to further that goal. Under the "less restrictive alternatives" test, "if there are other, reasonable ways to achieve [the State's] goals with a lesser burden on constitutionally protected activity, a State may not choose the way of greater interference. If it acts at all, it must choose less drastic nieans." "312

One "less drastic means" available for promoting the exposition of a range of idcas and viewpoimts on important public issues would be for the government to grant incentives for such coverage. Direct

important to justify the inhibition created. See, e.g., NAACP v. Alabama, 357 U.S. 449, 461, 466 (1958).

308. Fairness Report, supra note 60, at 11; Schmidt, supra note 99, at 216.

309. Schmidt, supra note 99 , at 216 .

310. 1975 Hearings, supra note 88, at 17 (statement of Sen. Proxmire).

311. See notes 274-303 and accompanying text supra.

312. Dunn v. Blumstem, 405 U.S. 330, 343 (1972). The classic statement of this principle was made in Shelton v. Tucker, 364 U.S. at 488 (footnotes omitted):

[E]ven though the governmental purpose be legitimate and substantial, that purpose cannot be pursued by a means that broadly stifles fundamental personal liberties when the end can be more narrowly achieved. The breadth of legislative abridgment must be viewed in the light of less drastic ineans for achieving the same basic purpose.

See also Kusper v. Pontikes, 414 U.S. 51, 59 (1973) ("If the State has open to it a less drastic way of satisfying its legitimate interests, it may not choose a legislative scheme that broadly stifles the exercise of fundamental personal liberties"). 
financial assistance, or variations such as favorable tax treatment or special consideration in the allocation of frequencies, are perhaps the most obvious methods, but these would not be the most desirable, due to the danger of government influence on the views espoused by assisted stations. ${ }^{313}$ Other possible inethods include general tax reduction, a reduction in postal charges, or a reduction of general busmess regulations.

Another means of imcreasing diversity would be to increase the number of frequency positions available for broadcasting. The emergence of cable television ${ }^{314}$ may reduce the necessity for such action, but it continues to hold promise for the diversification of broadcastimg. This option is exemplified by recent FCC proposals such as expansion of the AM radio band, ${ }^{315}$ reduction of the spectrum space required between AM stations, ${ }^{316}$ and the promotion of television "mini-stations." 317

A third possible means of promotimg diversification would be the strengthening and strict enforcement of cross and multiple ownership rules. ${ }^{318}$ This would increase the number of independent station owners, and would promote localisin as well by inaking local ownership more likely. ${ }^{319}$

If these options were pursued vigorously by the government, it would further the goal of imcreasing the accessibility of diverse viewpoints necessary for an informed citizenry, without a concurrent burden on broadcasters' exercise of free speech. Content regulation therefore represents a more restrictive alternative, exceeding the limitations placed on government action by the first amendment.

\section{CONCLUSION}

Congressional repeal of content regulation im broadcastimg, attempted several times in recent years, could become law in the near

313. See Schneyer, supra note 69 , at 668.

314. See notes $178-82$ and accompanying text supra.

315. See F.C.C. Docket 20271 (WARC Proceedings) (Dec. 5, 1978), cited in 1979 Hearings, supra note 89, at 2056 (letter from C. Ferris) (proposed expansion into $1605-1800 \mathrm{kHz}$ ).

316. Clear Channel Broadcasting in AM Broadcasting Band, FCC 80-317, adopted May 29, 1980.

317. Inquiry into the Future Role of Low Power Television Broadcasting and Television Translation in the National Telecommunications System, 45 Fed. Reg. 69,178 (1980).

318. FCC restrictions on inultiple ownership are found at 47 C.F.R. $\$ \S 73.35$ (c), 73.240, and 73.636 (1979). A recent Congressional attempt (H. 6228) to codify these rules passed the House after disabling amendments were excised. See S.F. Chron., Oct. 2, 1980, at 8, col. 3; 2 Cong. INDEX (CCH), Oct. 15, 1980, at 34,518 (bill effectively dead for this session of Congress).

319. Other possible means of promoting diversity include "eliminating the UHF handicaps, limiting the dominance of the networks, . . . and enabling other teclinologies to serve as additional outlets of local expression." Options PAPERs, supra note 4, at 77. 
future. If a repeal bill does pass, an individual or group probably would challenge the constitutionality of such an action in the courts, alleging that the first amendinent requires broadcasters to provide adequate access to information and opinions on controversial public issues. While the plaintiff in such an action would have standing before the court, and the broadcaster's actions in this regard could be considered state action for first aunendment purposes, judicially iniposed content regulation would not be consistent with the constitutional guarantees of free speech and a free press. Premised on an erroneous interpretation of the first amendment right to hear, it would inhibit the exercise of the broadcaster's right to free speeclı without furthering a compelling state interest. It also would imvite government abuse and curtail the press' important role in our dennocratic form of government. A lawsuit atteinpting to reestablish content regulation of the broadcast media should therefore fail.

David M. Coyne*

* B.A. 1978, State University of New York at Binghamton; third-year student, Boalt Hall School of Law. 